\title{
Decentralization, Market Integration and Efficiency-Equity Trade-Offs: Evidence from Joint Forest Management in Ethiopian Villages*
}

\author{
Dambala Gelo ${ }^{\mathrm{a}},{ }^{\mathrm{b}}$, Edwin Muchapondwa ${ }^{\mathrm{a}}$ and Steven F. $\mathrm{Koch}^{\mathrm{c}}$
}

\begin{abstract}
Extant literature on Joint Forest Management (JFM) impact evaluation has concluded that it generally does not provide sufficient incentives to justify the costs that forest use restrictions impose on local people. However, there is a dearth of evidence concerning whether alternative JFM intervention with improved market linkages for non-timber forest products has similar implications. In this study, we evaluated the income and distributive effects of a JFM program in Ethiopia in which additional support was provided for improved market linkages for non-timber forest products (NTFPs). Exploiting exogenous variation in customary rights across eligible groups of communities that participate in JFM programs, as well as using heteroskedasticitybased instrumentations, we identified the income and distributive effects of the program. Our analysis shows that the program has raised the income of the households who chose to participate by approximately 400 Ethiopian Birr or $26 \%$ of per capita expenditure; that result was robust to various specifications. We also found that this effect is largely driven by marketing incentives to use non-timber forest products. However, we found that the program's benefit is
\end{abstract}

\footnotetext{
* We thank associate editor, Professor Arild Angelsen, and the reviewer for their comments. We are grateful to Volkswagen Foundation and University of Johannesburg for funding postdoc fellowships of the first author and Economic Research Southern Africa for its support of this research. We also gratefully acknowledge generous financial support of EfD (EDRI/ EEPFE) SIDA for collection of the data used for analysis of this paper.

a School of Economics, University of Cape Town, Private Bag, Rondebosch 7701, Republic of South Africa, daatu24@yahoo.com, O) 27-21-650-1232

${ }^{\mathrm{b}}$ Chair of Econometrics, Department of Economics, University of Mannheim, daatu24@ yahoo.com

a School of Economics, University of Cape Town, Private Bag, Rondebosch 7701, Republic of South Africa, Edwin.Muchapondwa@uct.ac.za, (O) 27-21-650-5242

c Department of Economics, University of Pretoria, Private Bag X20, Hatfield 0028, Republic of South Africa, steve.koch@up.ac.za (O) 27-12-420-5285.
} 
biased toward the upper end of the income distribution, a result that points to the inequalityreinforcing effects of the program.

Key words: Treatment effect, JFM, market linkage, distributive effect

\section{Introduction}

Recent years have seen decentralization of natural forest management to local communities in many developing countries to counteract the economic and environmental ramifications of deforestation (Agrawal and Gibson, 1999; Agrawal and Ostrom, 2001; Bluffstone, 2008 and Bluffstone et al, 2013). These reforms followed decades of continued deforestation under the state property rights regime. ${ }^{1}$ Because these reforms have been based on theoretical predictions and anecdotal evidence from local case studies, rigorous empirical evaluation of the welfare, distributive and environmental impacts is needed. It is difficult to draw generalized conclusions about their impacts because the nature and extent of these reforms have varied across programs and countries (Bluffstone et al, 2013). In this study, we evaluated a Joint Forest Management (JFM) program in Ethiopia. We tested whether the JFM program, which was augmented by marketing support for non-timber forest products (NTFP), raises income (in terms of per capita expenditure) among rural households. Moreover, we tested whether there is distributional bias across poor and non-poor program participants. To do so, we exploited a policy (natural) experiment, in which some forest-using villages were able to access JFM, while other, similar villages were not.

\footnotetext{
${ }^{1}$ State regulation of natural forests has been constrained by insufficient budget, staffing and facilities (Kumar, 2002), coupled with imperfect incentives and prohibitively high information, monitoring and enforcement costs. This led to excessive extraction of both timber and non-timber products under open access regimes. Decentralization policies are based on the idea that resource management by people living adjacent to forests can be more viable and cost-effective than state enforcement (Agrawal and Gibson, 1999).
} 
Essentially, decentralization policies are intended to halt deforestation through stewardship of the existing forest stock. This entails exclusionary rules put into place to achieve ecological sustainability, as well as incentives for local communities to restrict forest harvesting and give up agricultural land expansion. Such incentives can come in the form of economic benefits realized through decentralized management of forests.

In the various countries where JFM has been adopted, there are two major concerns about whether such reforms can offer sufficient incentives for communities to forgo shorter-term benefits. First, more often than not, forestry management decentralization has taken the form of JFM, which aims at forest conservation by placing significant restrictions on forest harvests, charcoaling and agricultural encroachment, practices that have been shown to lead to deforestation and forest degradation under de facto open access regimes (Robinson and Lokina, 2012). In these cases, communities are granted limited entitlements in JFM programs, which appear to be insignificant as incentives for active participation in forest protection. For the most part, villagers are entitled to extract minor forest products, such as fuelwood, traditional medicines and non-timber products for domestic use only and are allowed to access ritual sites (Kajembe et al., 2005). In some cases, the rents accruing from improved forest stocks under JFM do not accrue to the local communities alone, but are shared with the state in the form of user's fees (Jumbe and Angelsen, 2006; Lemenih and Bekele, 2008; Robinson and Lokina, 2012). In either case, it is not clear whether the program's benefits outweigh the opportunity costs borne by members of these communities. ${ }^{2}$

\footnotetext{
${ }^{2}$ The net incentives are likely to be non-existent if we consider the forgone income from deterred agricultural land expansion. Potential agricultural income may increase as a result of rising prices for agricultural products or increasing agricultural productivity due to, for example, improved seed varieties, fertilizer, herbicides and other
} 
In particular, JFM program restrictions are likely to hurt the poor relative to the non-poor for the following major reasons. First, poor households often lack human capital, physical capital and land resources; therefore, they depend to a larger extent on extraction of natural forest resources as a basis of their livelihood using unskilled labor. Thus, a lower opportunity cost of their labor i.e., lack of alternative opportunity to sell their labor at high wages, means that they are likely to bear higher opportunity costs with JFM participation and consequently suffer more negative welfare effects than are their non-poor counterparts.

The success of the program thus depends on providing alternative incentives to farmers to encourage them to endure short-term losses in favor of medium- to long-term payoffs.

One innovative design, described in detail in Section 2 below, confers usufruct rights for nontimber forest products and augments this with improved marketing of these products (Vega and Keenan, 2014).

Previous literature confirmed that JFM was successful in regenerating the forest resource (Edmonds, 2002; Takahashi and Todo, 2012) and offered mixed welfare outcomes, but mostly reduced income for the poor (Kumar, 2002; Jumbe and Angelsen, 2006; Adhikari, 2005). However, there is a paucity of evidence on whether the same conclusions hold for JFM programs that are augmented by marketing support for forest products. Evidence on income and distributive effects of such augmented programs is anecdotal and limited to qualitative case studies.

technologies (Gelo and Koch, 2014). In that case, the opportunity cost of committing forest land to standing forest instead of converting it into agriculture may not be compensated by income from JFM. 
Although Gelo and Koch (2014) confirmed that JFM has increased revenue generated from NTFP, they did not empirically tie it to income and its distribution. Similarly, Ameha et al. (2014a) confirmed that JFM raised forest income from the sale of timber products, but did not result in a corresponding change in total income.

Moreover, while a few studies have evaluated the efficacy of a combination of property rights reform with provision of market-based incentives (Ameha et al., 2014a; Vega and Keenan, 2014; Gelo and Koch, 2014), they did not separate the effect of each component.

The present study is motivated by these empirical uncertainties. It is aimed at evaluating the income and distributive effects of a JFM program augmented by market linkage interventions.

Using survey data from the Gimbo district, southwestern Ethiopia, we estimated the treatment effect of participation in the JFM program. We used participation in the program as a treatment variable and per capita consumption expenditure per annum, including goods produced at home and valued at village prices, as the outcome variable. ${ }^{3}$ Moreover, we estimated the difference in the treatment effect across poor and non-poor participants to ascertain whether there is a bias in distribution of the income arising from the program. For the analysis, we used a combination of econometric methods, including ordinary least square (OLS), propensity score matching (PSM) and variants of instrumental variable (IV) methods to identify the average treatment effect (welfare change) of the program. In addition, we used the IV-based Oaxaca (1973) method to disentangle the treatment effect gap between poor and non-poor program participants.

\footnotetext{
${ }^{3}$ Section 4 discusses the rationale for using per capita expenditure as a proxy for income.
} 
Our results provide support for the hypothesis that JFM programs augmented with market access support offer significant income gain, on average, but the distribution of that benefit is biased toward non-poor participants. Specifically, we found that the program has raised average income by 400 Ethiopian Birr or $26 \%$ of per capita expenditure, but this effect is limited to participants in upper end (median and above) of the income distribution. Moreover, our analysis suggests that this effect is largely driven by the marketing component of the JFM program.

The remainder of the paper is organized as follows. Section 2 describes the process and nature of the decentralization of forest resources management in Ethiopia and our study area. Section 3 describes the data collection efforts, while Section 4 discusses the econometric framework that informed the empirical strategies. Section 5 presents and discusses the results. Finally, Section 6 concludes the analysis with key findings and policy implications.

\section{The Program and Evaluation Problem}

In recognition of the importance of forest resources, and in response to decades of deforestation and forest degradation under the regime of state control, Ethiopia has recently reviewed its longstanding forestry policies and begun to implement decentralization of natural forest management to the communities located near that resource (Ameha et al., 2014b; Gelo and Koch, 2014). From that policy, a number of JFM programs have been implemented across the country by various bilateral donors, such as GTZ and JICA, as well as NGOs, including FARM Africa and SOSSahel (Tesfaye et al., 2010; Kubsa et al., 2003). The general objectives of these programs are to arrest deforestation and forest degradation while improving the welfare of those who are heavily dependent on the forest for their livelihoods. 
In essence, the programs are intended to achieve these twin goals by incentivizing local communities to manage state forests. However, there are pervasive imperfections in forest products markets that constrain the needed incentives; these imperfections arise mainly from limited infrastructure, high transport costs, few buyers, exploitive marketing chains and imperfect price information. One innovative approach to overcome these problems, which has been adopted by the Ethiopian government, is to organize JFM into community forest enterprises (CFE) in the form of forest users' cooperatives (FUC) for forest products marketing. ${ }^{4}$ This provides the community with avenues for greater participation in value chains of forest products markets through vertical integration (VI) (Antinori, 2005; Gelo and Koch, 2014; Vega and Keenan, 2014). Vertical integration is expected to raise NTFP prices and hence spurs the required incentives by shortening the marketing chain and increasing bargaining power of farmers along NTFP market value chain.

Against this backdrop, Farm Africa/SOS-Sahel started implementing JFM programs in 2001 (Lemenih and Bekele, 2008), culminating in the management of about 34000 ha of forests in the Bonga region (Ameha, 2014b). In light of the two-pronged objectives, Farm Africa/SOS-Sahel targeted forests with the potential threat of deforestation and communities that depended heavily on those forests. Once identified, forest units were demarcated in the field. Within the provisionally identified forest units, information related to available forest resources was required, as was information related to past and present management practices. Finally, it was necessary to understand prevailing management problems, forest uses and user needs (Lemenih and Bekele, 2008).

\footnotetext{
${ }^{4}$ In fact, this institutional innovation should be leveraged with infrastructure and technical support to attain its greatest benefits.
} 
One of the key observations that emerged from this multi-step process was heterogeneity of forest using communities in terms of customary rights to the forests ${ }^{5}$. Specifically, two groups of communities were identified, namely, native population and resettled population (new settlers who arrived from outside). Across these groups, perceptions of property rights to forests varied. In particular, the native population perceives the forest as belonging to them (as a group) and views state ownership as the government's attempt to take it over. However, new settlers see the forest resources as being open to all. Whereas the former group is construed as having customary rights to forests, the latter does not qualify for such a claim for historical reasons (Stellmacher, 2007). ${ }^{6}$ Moreover, from the federal and local government's point of view, such perceptions and the consequent forest use behavior were construed as trespass of forest conservation rules, but these entities failed to enforce rules due to high monitoring and enforcement costs, coupled with significant budget constraints. Consequently, the forest was subjected to an institutional vacuum

\footnotetext{
${ }^{5}$ This is referred to as the investigation phase of the JFM programs (Lemenih and Bekele, 2008). This process also contributed information that agricultural encroachment into forests, illegal logging, and the harvest of fuelwood (for either direct sale or charcoal production) appeared to be potential deforestation threats (Lemenih and Bekele, 2008; Bekele and Bekele, 2005).

${ }^{6}$ Historical episodes led to this variation in perceptions of customary rights; this is not surprising, as natural resources and land property rights are path-dependent, i.e., historical development affects their present situation. Prior to the 1974 Ethiopian revolution, forests in the Kaffa region were managed under a feudal system. The landlords had come into the regions from north and central Ethiopia and legally owned forest lands (Stellmacher, 2007). They granted long-term use rights to local peasants, the present native population (Menjas), who were living within or adjacent to the forests, and in turn received use "fees" paid in kind (mainly honey). The management of forest coffee and other forest products followed informal rules and regulations, traditionally laid down in the local institutional system. The new military government, commonly called the Derg, which emerged from the 1974 revolution, dissolved the feudal system, and landlords were dispossessed in 1975 through nationalization of all land resources, including farm land, grazing land and forests (Stellmacher, 2007). From this time onward, the forest resources of Kaffa and other regions fell under direct possession of the state, which caused longstanding negative impacts on the relationship between government and local communities (ibid). However, the Menjas and Kaffa people (native population) in the Bonga and Kaffa zones continued to perceive the forests as theirs and to use them in a situation of tolerated illegality (Stellmacher, 2007). Another relevant historical episode in the Bonga/Kaffa zone was government-initiated resettlement (villagization) programs in the 1980s. In response to famine, the Derg government resettled people from drought-stricken areas of Ethiopia to wet and widely forested areas of the country, including Bonga and Kaffa (Alemneh, 1990). The new settlers are heterogeneous in terms of ethnic and geographic origin, which made them less likely to perceive the forests as belonging to anyone, instead seeing them as open access resources and using them accordingly.
} 
without definite and enforceable institutions regulating access, a situation often referred to as a de facto open access property right regime.

Farm Africa, thus, had to set criteria in targeting a particular forest for intervention. In consultation with local government and communities, it devised three major criteria: (i) whether the forest has potential to produce non-timber forest products (ii) whether the forest was used under claim of customary right by the native population and (iii) whether the community (native or settlers) were primary users of the forest. The latter criterion took account of use by both the native population and new settlers (Stellmacher, 2007) and was determined by proximity to the targeted forest and frequency of use (Ameha, 2014b; Lemenih and Bekele, 2008; Bekele and Bekele, 2005). ${ }^{7}$

Once forests were selected, the decision whether to participate in JFM was voluntary. In 2004, eligible households that chose to participate in the JFM program formed Forest User Groups (FUG), which later developed into Forest Users Cooperatives (FUC). Those choosing not to participate had to revert to using the nearest non-JFM forest, which, in effect, is a forest that operates under the status quo: it is unregulated, and access is open to all. It is assumed that the participation decision was determined by the perceived costs and benefits of JFM, a perception that is likely to be affected by training. However, there are reasons to believe that the participation decisions are likely to vary with whether one belongs to the native population or new settlers population, as well as whether one's joint forest user group is ethnically heterogeneous.

\footnotetext{
${ }^{7}$ Primary users are those who use the forest more frequently, permanently or directly, whereas secondary users are those with less frequent use and who are far from the forest boundary (Lemenih and Bekele, 2008).
} 
We expect that native households were more likely than new settler households to participate. First, the JFM program involved, inter alia, granting usufruct to the locals to use and manage the forests. Thus, accessing and managing forests under JFM, to a large extent, parallels the historical experience of the forest usufruct property rights regime that prevailed in the region during Ethiopia's feudal era (see footnote 6) compared to complete control of the forest by the state. At this point, it is noteworthy that the feudal era forest use right experience underpinned the contemporary perceptions of customary rights among the natives, i.e., that the forest naturally belongs to them instead of being controlled by the state. Thus, JFM governance is likely to reinforce this perception and give more encouragement to households in the native population to participate in the program, compared to households in the new settlers group.

Second, we expect that participation in JFM is likely to be low among heterogeneous groups of new settlers compared to homogeneous groups. However, although this hypothesis is consistent with Ostrom's (2005, 2009) contextual variables hypothesis of determinants of successful collective action, there is still lack of consensus regarding the impact of heterogeneity on collective action (Baland and Plataeu, 1999; Varughese and Ostrom, 2001; Poteete and Ostrom, 2004). ${ }^{8}$

Once intervention sites and participants in the program had been identified, the remaining key elements of JFM intervention - crafting common property right forest management institutions (rules) and establishing enforcement mechanisms - were put in place. The process of rule setting and establishing the attendant community organization involved a range of complex procedures. Farm Africa/SOS-Sahel began the process with negotiations and discussions with all

\footnotetext{
${ }^{8}$ We thank our referee for sharpening our discussion on this point.
} 
stakeholders. However, because skepticism regarding JFM was rife within both the local government and the local communities, Farm Africa/SOS-Sahel provided JFM training for all eligible households (Bekele and Bekele, 2005). ${ }^{9}$

The formation of Forest User Groups/Forest User Cooperatives (FUG/FUC) came into effect following the framing of rules (institutions) and the setting up of organizational components (often known as nested enterprises in the commons literature). As the JFM is a co-management system, determination of the authority for making constitutional, collective choice and operational level rules was not left to the FUG/FUC alone; rather, these processes involved experts from Farm Africa/SOS-Sahel and local government. At an operational level, the rules comprise (i) stipulations relating to quantity and types of forest products allowed for use by members; (ii) stipulations concerning distribution of revenues for commercially valuable NTFPs; (iii) enforcement rules surrounding protection from fire, vandalism (including unauthorized tree cutting) and agricultural encroachment (clearing forest for agricultural land acquisition); and (iv) forest development (management) rules regarding the planting of new trees for the enrichment of the existing forest.

Within the bounds of this institutional framework, each individual member enjoys the following rights in common with, and exclusive to, members of the FUC: (1) to graze or cut grass in the forest for livestock production, to cut live trees or parts of trees for farm implements and construction, and to hang beehives, all of which are subject to FUG/FUC executive approval and

\footnotetext{
${ }^{9}$ The process referred to as the "negotiation stage" includes discussions with all stakeholders to determine eligible households; developing a Forest Management Plan (FMP); setting rules; establishing the attendant community organization; and providing training for all eligible households and local government personnel (Lemenih and Bekele, 2008).
} 
(2) to extract a range of non-timber forest products, medicinal plants and firewood from dead trees, for both own consumption and market sale. ${ }^{10}$

NTFPs including forest coffee, honey and spices are harvested mainly for commercial purposes. Each FUC member may collect these products and deliver them to the FUC, which, in turn, supplies them to national and international markets and disburses the proceeds to its members in the form of dividends. The FUC retains 30\% of total income (profit) (Bekele and Bekele, 2005; Lemenih and Bekele, 2008), whereas the remaining $70 \%$ is distributed to individual members according to the quantity and types of NTFP supplied by each individual member. ${ }^{11}$

In terms of the causal chain, JFM interventions - program forest identification, community and personnel training, stakeholder's analysis and negotiation - give rise to the FUC organization and rules. ${ }^{12}$ The FUC, in turn, yields a range of intended outcomes, including increased forest cover/stock (Bekele and Bekele, 2005; Limenih and Bekele, 2008; Gobeze et al., 2009) and improved farmer access to new, fair and sustainable market opportunities to receive higher prices for NTFPs along the value chain (Shumeta et al., 2012; SOS SAHEL, 2007 and Gelo and Koch, 2014), both of which bolster the income benefits of program participation.

\footnotetext{
${ }^{10}$ Although they have the exclusive right to use or extract these products and hence are quasi-owners, they don't have an exclusive right to a fixed quantity of the products. Any member of the group can extract or use them at any rate desired. This is called an unregulated common property right structure. Note also that firewood and medicinal plants are solely for own consumption.

${ }^{11}$ This stands in sharp contrast with non-JFM forest users, where neither access rights nor use rights are defined for forest products. They often collect forest coffee, honey and other NTFP under an institutional vacuum and sell them to traders, sometime to the FUC itself at local markets, often at lower prices due to weak bargaining power and asymmetric price information.

${ }^{12}$ In mapping out the causal mechanism through which participation in JFM (i.e., membership in a FUC) leads to a change in income (treatment effect), we draw on the theory of change that is common in program evaluation literature. This framework outlines a results chain, which sets out the sequence of program inputs, activities, and outputs that are expected to improve intermediate and final outcomes associated with the intervention (Gertler et al. 2010).
} 
However, the program also entails costs, which may vary across participants depending on the degree to which a household makes its living from forest-based activities. Program participation costs include immediate sacrifice of free forest access in the newly established program forest and the costs of harvest restrictions imposed by the program. For some households, these costs involve forgone benefits that could be derived from the production and sale of firewood and charcoal, as well as the benefit that could have been earned from forestland cleared for agricultural production. Moreover, participation in the program entails direct costs, typically the opportunity cost of time spent on meetings and patrolling and managing JFM forests.

Recent studies in the region confirm that the opportunity costs are real. In particular, Limenih and Bekele (2008) showed that the program has reduced free grazing of livestock within the forest, cut back agricultural encroachment and slashed the extraction of forest resources for the production and sale of charcoal and firewood (Gobeze et al., 2009). Through difference-indifference (DID) evaluation, Gelo and Koch (2014) showed that these effects are observed in the villages selected for our analysis.

If the program's income benefits outweigh its costs - measured as the sum of opportunity costs (income losses) and direct costs, then the resultant net benefit bolsters consumption directly via raising total income and indirectly through two amplifying effects. First, the multiplicity and seasonal distribution of NTFPs means that this benefit accrues steadily and hence stabilizes overall annual income. ${ }^{13}$ Thus, stability in total income is likely to raise consumption via

\footnotetext{
${ }^{13}$ Market integration of NTFP, as the result of JFM intervention, would mean increased prices and reduced price fluctuation of these products, which, in turn, translates into higher and more stable returns to their extraction. Note also that different NTFPs (forest coffee, honey and various species) become ripe for harvest at different times of the year (Stellmacher and Grote, 2011; Shenkute, 2012 and Meaton et.al, 2015), providing income throughout the year,
} 
lessening precautionary saving. Second, in the face of limited access to credit, increased net income, especially that arising from increased NTFP prices, relaxes liquidity constraints to engaging in profitable investments in agricultural production and off-farm employment (e.g., petty trade), each of which raises total income, thereby leading to greater consumption.

In sum, the empirical context presented here poses two major evaluation questions. First, it is uncertain whether the program benefits arising from direct and indirect mechanisms outweigh the cost of participating in the program and are translated into higher income for the average participant. Second, it is not clear whether that change in income varies across poor and nonpoor program participants in light of the heterogeneous opportunity cost and direct cost of participation across these groups.

\section{Econometric framework}

Our analysis draws on theoretical foundations due to Roy (1951). Accordingly, farmers choose whether or not to participate in the JFM program, and that decision is assumed to depend on the farmer's expectation of the income gain associated with participation in the program, relative to the status quo. In this study, income is measured by per capita consumption expenditure. If farmer $i=\{1,2, \ldots, N\}$ chooses to participate (if $D_{i}=1$ ), the relevant household outcome is $Y_{1 i}$; $Y_{0 i}$ is the relevant outcome for non-participating $\left(D_{i}=0\right)$ households. Therefore, in regression format, $Y_{i}=Y_{0 i}+D_{i}\left(Y_{1 i}-Y_{0 i}\right)+\eta_{i}=\alpha+\tau D_{i}+\eta_{i}$. Because participation is voluntary, the

compared to farming, which provides seasonal and often fluctuating income. Commonly, income from NTFP extraction is less risky compared to farming income, in which case households use NTFP extraction as a risk-free asset to smooth income fluctuations (Delacote, 2007; Alderman and Paxson, 1994). Furthermore, greater integration of NTFP markets relative to agricultural markets in our study areas would mean that income from NTFP extraction and farming are not correlated. Consequently, NTFP extraction not only serves as a counter-seasonal income source, but stabilizes overall income across states of nature by cushioning farming income shortfalls during bad years. 
outcome is not likely to be independent of the treatment choice, such that treatment is not independent of the error term in the previous regression. Therefore, additional assumptions are needed in order to estimate the treatment impact.

Assuming that the distribution of welfare outcomes, $Y_{1 i}$ and $Y_{0 i}$, are independent of treatment $D_{i}$, and given a vector of covariates $X_{i}$, a propensity score matching estimator for the average effect of treatment on the treated can be derived. Intuitively, the goal of matching is to create a control group of non-JFM participants that is as similar as possible to the treatment group of JFM participants, although the groups differ in terms of their participation. Identification of the average effect of JFM on the program participants, via ordinary least square (OLS) regression or propensity score matching (PSM), requires the strict ignorability of treatment, $\left(Y_{1 i} Y_{0 i}\right) \perp D_{i} \mid X_{i}$.

However, if there are unobservable determinants of participation, then treatment assignment is non-ignorable, and treatment effect results based on OLS or PSM estimators are biased. Under non-ignorable assignment to treatment, control function methods (selectivity models) or IV approaches are needed instead (Heckman and Navarro-Lozano, 2004 and Heckman and Vytlacil, 2005).

In what follows, we more carefully describe the causal effect of interest. The data is comprised of $n$ observations, and the outcome variable $Y_{i}$, per capita expenditure, is continuously distributed. There is a binary treatment variable, denoted by $D_{i}$, as well as vectors of covariates, $X$, and instrumental variables, $Z$. We specify the relationship between observed per capita expenditure and the treatment variable as

$$
Y_{i}=Y_{0 i}+D_{i}\left(Y_{1 i}-Y_{0 i}\right)+\eta_{i}=\alpha+\tau D_{i}+\left\{D_{i},\left(u_{1 i}-u_{0 i}\right)+u_{0 i}\right\}
$$


The average treatment effect and/or treatment effect on the treated is derived from (1) as follows, after certain algebraic manipulations:

$E\left(Y_{1 i} \mid D_{i}=1, X\right)-E\left(Y_{0 i} \mid D_{i}=0, X\right)$

$=E(\tau \mid X)+E\left(u_{1 i}-u_{0 i} \mid D_{i}=1, X\right)+E\left\{\left(u_{0 i} \mid D_{i}=1, X\right)-E\left(u_{0 i} \mid D_{i}=0, X\right)\right\}$

where the first term in RHS of (2) is average treatment effect on the treated (ATT). The second term in (2), referred to as treatment effect heterogeneity, is the idiosyncratic income gain from the program for those who decided to participate in the program. If this term is zero, endogeneity arises only from the last term in curly brackets of (2), which is the counterfactual: the difference between the per capita expenditure of a program participant (treated) that would have been realized if he did not participate and the observed per capita expenditure of a non-participant (untreated) individual. If this difference is greater than zero, it follows that those individuals who would have done well without program participation in terms of unobservables, $u_{0 i}$, decided to participate in the program. In other words, cov $\left(u_{0 i}, D_{i}\right) \neq 0$, leading to biased OLS and PSM and estimates of the treatment effect on the treated. In that case, identification is achieved through selection models and traditional 2SLS (Heckman and Vytlacil, 2005).

However, the story takes a different course if the treatment effect heterogeneity is non-zero, i.e., $E\left(u_{1 i}-u_{0 i} \mid D_{i}=1, X\right) \neq 0$. If the program participation decision is made with the individual's knowledge and anticipation of this idiosyncratic gain, a condition called essential heterogeneity or sorting gain in the literature, then a traditional 2SLS estimator would not identify the treatment effect (Heckman and Vytlacil, 2005 and Basu et al., 2007). However, if 
idiosyncratic gain exists, but selection into the treatment (program) does not depend on it, ${ }^{14}$ a conventional 2SLS can identify the treatment effect.

In this study, we employed a broader set of identification strategies to estimate the treatment effect estimate in (2). As baseline specifications, we implemented an OLS model and propensity score matching models. We then extended these models to various specifications of instrumental variables (IV) methods to control for endogeneity bias. The choice of IV method was informed by the test for endogeneity and its source. Following Heckman et al. (2006) and Heckman and Vytlacil (2001), we tested whether the endogeneity arises from essential heterogeneity (sorting gain) to inform our choice of alternative specifications of correcting endogeneity bias. ${ }^{15}$ Failure to reject the null hypothesis of no essential heterogeneity warrants a conclusion that IV models can be used to identify the treatment effect.

In the interest of testing for robustness of our results, we employed alternative IV specifications.

In the initial analysis, we instrumented endogenous program participation by a binary variable defined as whether a household belongs to a village where the native population (Menjas) is prevalent. Hereafter, we call this "Menjas prevalence." This instrument captures variation in perception of customary rights over the forest selected for intervention, which was in turn driven by variation in the feudal era experience of managing forests under usufruct. As such, the former

\footnotetext{
${ }^{14}$ In the literature, this is referred to as non-essential heterogeneity.

${ }^{15}$ The seminal estimator, developed by Heckman et al. (2006) to control for endogeneity bias that arises under the situation of treatment effect heterogeneity, involves two steps. In the first step, a probit model is used to estimate the probability of treatment take-up (program participation) and the predicted value, the propensity score, is thus generated from this step. In the second step, a semi-parametric procedure of local polynomial regressions is used to retrieve the marginal treatment effect. In the interest of space, we refer readers to Heckman et al. (2006), Heckman and Vytlacil, (2005), Ichimura and Todd, (2007) and Basu (2007).
} 
is determined by historical events and is, thus, exogenous to per capita consumption. However, it is expected to drive participation in the JFM, as elucidated in Section 2. One may expect that, apart from variation in perceptions of customary rights, the two groups may vary in terms of market and technology parameters, institutional arrangements, social capital and underlying condition of the forest near which they live, all of which can be related to both program participation and the outcome variable (per capita consumption or income). ${ }^{16}$ In light of this worry, following Abadie (2003) and Frölich (2007), we conditioned our IV (Menjas prevalence) on the following baseline (pre-projects) covariates: distance to market, distance to road, distance to agricultural extension office, forest condition (deforestation status) and measures of institutions and social capital to authenticate its validity (exclusion restriction). Note, though, that this specification is an intention to treat strategy and, thus, estimates local average treatment effect (LATE) rather than average treatment effect (ATE). ${ }^{17}$ Second, we combined it with other instruments to test the exclusion restrictions. The first combination involved variables associated with the Menjas population - the density of the Menjas population in the village and the total number of Menjas households in the village. For robustness, we also combined it with a set of instruments, including baseline covariates such as households' experience with collective action

\footnotetext{
${ }^{16}$ Although we don't have a priori expectations that the two population groups may vary in terms of access to markets, technology and environmental resources, they are bound to experience different cultural and institutional backgrounds. Of interest are differences in institutional arrangements and social networks that govern transactions and correct coordination failures within a local economy. To ascertain such differences, we tested whether there is a difference across these groups in terms of participating in iddir. "Iddir" is a social network that pervades both rural and urban communities in Ethiopia. While its primary function is providing group-based informal insurance, researchers find that it also plays a critical role in overcoming market imperfections by expediting the flow of information within and beyond the village, reducing monitoring and enforcement costs (Berhane et al., 2009; Abay et al., 2014) and developing trust among agents (Caeyers and Dercon, 2012). In some casea, via institutional arrangements nested within it, it corrects coordination failures in the management of communal natural resources (Stellmacher and Mollinga, 2009). Our test statistics show no difference in participation rates in this social network between the native and new settlers' communities. We also found that, for the most part, they participate in the same iddir.

${ }^{17}$ LATE is the treatment effect parameter for the subpopulation of compliers, where the compliers are all individuals whose value of treatment (JFM membership in our case), D, would change if the instrument, Z (Menjas prevalence), changes exogenously (Imbens and Angrist, 1994).
} 
prior to the program, distance from the JFM forest before the beginning of the program and number of ethnic groups in a village under different configurations. ${ }^{18}$

Third, we employed the recently developed heteroskedasticity-based instrumentation of Lewbel (2012), which identifies structural parameters in regression models with an endogenous regressor in the absence of traditional external instruments or repeated measurements. Identification is obtained by using regressors that are uncorrelated with the product of heteroskedastic errors, a feature that characterizes many models in which error correlations are due to an unobserved common factor (Lewbel, 2012). ${ }^{19}$ In our analysis, in addition to implementing this estimator, we used internally generated IVs from the model to supplement our original IV (Menjas prevalence). However, these models only estimate the welfare impact of combining property rights reform with provision of market-based incentives to use NTFPs, but do not isolate the effect of each component. Thus, exploiting a multi-treatment structure in our sample - a program without marketing incentives, programs with marketing incentives and a control group -we separated the effects of property rights reform from the effects of marketing incentives to use NTFPs. ${ }^{20}$ Following Cattaneo (2010), we used a semi-parametric multi-valued treatment model for the analysis.

\section{Income gap decomposition analysis}

In addition to estimating return to program participation (treatment effect), we test the difference

\footnotetext{
${ }^{18}$ Note that these variables are important determinants of program participation. However, they preceded per capita expenditure by many years (i.e., are predetermined), making it unlikely that they directly affect the latter.

${ }^{19}$ Common factors in our case are unobserved covariates that drive both participation in the program and per capita consumption (income). For brevity, we skip further discussions of this estimator and, instead, refer to Lewbel (2012).

${ }^{20}$ One of our sample villages, although designated as a forest users group, was not transformed into a forest users cooperative until our survey year, 2009. Therefore, we expect that members of this group do not benefit from marketing components of the program as much as FUC members do.
} 
in treatment effects between poor and non-poor program participants, in order to unpack distributional bias in the program. First, we distinguish between poor and non-poor household participants. Poor households are those whose daily income is below the national poverty line of ETB10.36 (US\$0.80) per person per day (Ethiopian Ministry of Finance and Economic Development, 2012), while non-poor households are those above this line. Thus per capita income for non-poor and poor subsamples is given by

$$
\text { Let } Y_{i}=\left\{\begin{array}{c}
Y_{\text {inp }}=\beta_{n p} X_{\text {inp }}+\varepsilon_{\text {inp }} \text { if } i=\text { non-poor } \\
Y_{i p}=\beta_{p} X_{i p}+\varepsilon_{\text {ip }}, \text { if } i=\text { poor }
\end{array}\right.
$$

where $Y_{i}$ is individual $i^{\text {th }}$ per capita income and $\beta_{n p}$ and $\beta_{n}$ are the respective coefficients of the determinants, $X=\left\{X_{i n p}, X_{i p}\right\}$, of per capita income for non-poor (np) and poor (p) subsamples. The income gap between the poor and non-poor subsample thus equals $\mathrm{E}\left(Y_{i n p}\right)-E\left(Y_{i p}\right)=E\left(\beta_{n p} X_{i n p}+\varepsilon_{n p}\right)-E\left(\beta_{p} X_{i p}+\varepsilon_{p}\right)=\beta_{n p} \bar{X}_{n p}-\beta_{p} \bar{X}_{p}$ where $E\left(\varepsilon_{n p}\right)=E\left(\varepsilon_{p}\right)=0$. Note that equation (4) also can be re-arranged as $\left.\left.\mathrm{E}\left(Y_{i n p}\right)-E\left(Y_{i p}\right)=\left(\beta_{n p}-\beta_{p}\right)^{\prime} \bar{X}_{p}+\overline{(X}_{i n p}-\bar{X}_{p}\right)^{\prime} \beta_{n p}+\overline{(X}_{i n p}-\bar{X}_{p}\right)^{\prime}\left(\beta_{n p}-\beta_{p}\right)$

Equation (5) is the Oaxaca (1973) decomposition (OXB) equation and shows that the average income gap between poor and non-poor is due to either (i) the differences in the effects, $\left(\beta_{n p}-\right.$ $\left.\beta_{p}\right)$, of covariates on income or (ii) the differences in the mean, $\left.\overline{(X}_{i n p}-\bar{X}_{p}\right)$, of covariates across the groups or (iii) both. Although the entire set of covariates, $X$, matters for explaining the average income gap in (5), of interest for our analysis is a treatment variable, $D$. Thus, by maintaining the notational convention of treatment effect as $\tau$ from (2) and by testing whether the difference in treatment effects (coefficients of D), $\tau_{n p}-\tau_{p}>0$, holds across poor and nonpoor subsamples, we can ascertain the distributional bias of the program. This involves two steps: first we estimate and identify $\tau_{n p}$ and $\tau_{p}$ separately for both poor and non-poor groups via 
an IV method; then, we implement Oaxaca decomposition in (5) (Jann, 2008). ${ }^{21}$

\section{The Data}

Data for the analysis was obtained from a household survey, designed for this study, undertaken in 10 Ethiopian villages in October of 2009.The villages are located in the Gimbo District, which is in southwestern Ethiopia. Sample frames for the survey were derived from the selected villages, via the lower level of local government, the "kebele". The analysis was based on randomly selected households from these villages: 200 from JFM villages and 177 from nonJFM villages. Table 1 outlines the "kebeles" and the villages within the kebeles, including JFM

Table 1. Sample Villages and Respective Sample Sizes

\begin{tabular}{lccc}
\hline List of Kebeles & Number of villages & \multicolumn{2}{c}{ Name of villages } \\
& 2 & PFM villages & Non-PFM villages \\
Yebito (88) & 1 & Agama (58) & Mula - Hindata (30) \\
$\begin{array}{l}\text { BitaChega(49) } \\
\text { Michiti (80) }\end{array}$ & 3 & Beka (32), Matapha (24) & Chira - Botera (24) \\
$\begin{array}{l}\text { WokaAraba (50) } \\
\text { KejaAraba (47) }\end{array}$ & 1 & Woka-Araba (50) \\
Maligawa (63) & 2 & Sheka (37) & Keja-Araba (47) \\
Total & 10 & 200 & Shek (26) \\
\hline
\end{tabular}

participants and non-participants, and the number of survey respondents in each. The JFM villages were selected based on the criterion that the FUG had been transformed into a FUC.

\footnotetext{
${ }^{21}$ In traditional OXB, parameters, $\tau_{n p}$ and $\tau_{p}$ are often estimated through OLS assuming exogenous treatment (ignorability assumption). Note also that the Oaxaca estimator does both steps at once.
} 
FUC participants enjoyed the additional benefit of marketing assistance, compared to those who continued to participate in the earlier institutional form, the FUG, which did not receive such assistance.

Respondents provided information on participation in the JFM program and household characteristics. These included information related to whether any adult member of a household is a member of the program; household's characteristics, such as age, education, gender, and family size; household expenditure on various goods and services; household earnings from the sale of various goods and services; the labor allocated to harvesting forest products and to other activities (e.g., off-farm activities); distance to nearest town; and distance to the nearest road. Additional information pertaining to household circumstances that prevailed immediately before the inception of JFM in 2004, such as household assets, the household head's education and age, participation in off-farm employment, ownership of private trees, access to extension services, experiences related to alternative collective action arrangements, and household's distance from both JFM and alternative forests was also obtained. ${ }^{22}$ Finally, data related to the community including Menjas prevalence, population, ethnic structure, forest status and location was gathered.

With regard to the choice of outcome variables for the analysis, we use per capita consumption expenditure, including goods produced at home (which were valued at village prices), rather than income, as a welfare measure, for the following reasons. First, by virtue of consumption

\footnotetext{
${ }^{22}$ Note that we refer to 2004 and 2009 as the "before JFM" and "after JFM" data collection years. We believe that farmers easily recalled information from 2004 about their assets, alternative employment, access to public services and markets, and engagement in other collective action schemes. These covariates are expected determinants of JFM participation.
} 
smoothing, consumption expenditure fluctuates less than income in the short run. Second, consumption expenditure provides information about the consumption bundle that fits within the household's budget, although credit market access and household savings affect that. Similarly, it is easily interpreted and widely used (Skoufias and Katatyama, 2010). As such, consumption is generally believed to provide better evidence than income of the standard of living.

In terms of potential observable controls/baseline covariates, there are a number of significant differences between participant and non-participant households. The results show that participating households are located in areas that are nearly $38 \%$ more likely to incorporate individuals from the native population. Participating households are located nearly 45 minutes closer to program forests, based on walking times. They are also nearly 10 minutes closer to the nearest road, again measured by walking times. However, these households are located 54 minutes (walking time) farther away from the nearest non-program forest. On the other hand, participating households were $10 \%$ more likely to have previously participated in other collective programs. Also, before the program was started, participating households were $6 \%$ more likely to have a household member working off of the farm. Finally, participating households own more livestock, as measured in tropical livestock units.

The lack of balance for some baseline covariates across participants (the treatment group) and non-participants (the comparison group) meant that the outcomes for the latter group cannot be used as a counterfactual of participant outcomes. Estimating the simple mean difference of per capita expenditure to estimate treatment effect thus yields biased results. This problem necessitates drawing on an alternative method of program evaluation. As noted above, we solve 
this problem via OLS, matching and IV methods.

\section{Results and discussion}

\section{Who participates in JFM?}

Before analyzing JFM impacts, we first identify factors that encourage or deter participation in the JFM program, via estimating logit models. Table 3 reports estimates of two logit models, one for the entire sample and the other for households from eligible villages (villages targeted for JFM). For each model, we present the marginal effects based on the means of the data. Results suggest that the household characteristics and village-level factors described in the foregoing section are statistically significant determinants of the decision to participate in the program, and we also found that these results resonate with the mean differences highlighted in Table 2. Consistent with that discussion, the distance between the program forest and agricultural extension service office is negatively associated with household participation, suggesting that proximity to the extension office could have influenced the government's program location decisions and, thus, influenced participation. Similarly, households residing closer to the program forest were more likely to join the program, while those residing farther from alternative forests are also more likely to have joined, suggesting that opportunity costs associated with distance do matter. It is also true that those households that have experience with other collective action programs are more likely to participate, presumably due to positive experiences. We also find that, if a household member was engaged in off-farm employment before the program began, the household was more likely to participate in the program. Moreover, Menjas prevalence in the village drives participation in the program. This supports our prior belief that Menjas prevalence is an adequate instrument for participation in the program 
Table 2. Descriptive Statistics

\begin{tabular}{|c|c|c|c|c|}
\hline VARIABLES & & JFM-participant & Non-participant & Mean Difference \\
\hline Per Capita Consumption & HH consumption per HH member & $\begin{array}{c}1,734^{* * *} \\
(66.74)\end{array}$ & $\begin{array}{c}1,692^{* * *} \\
(62.18)\end{array}$ & $\begin{array}{c}20.54 \\
(88.81)\end{array}$ \\
\hline Off-farm Labor (After JFM) & $\begin{array}{l}\text { Off-farm labor market participation after } \\
\text { JFM implementation }\end{array}$ & $\begin{array}{l}0.145^{* * *} \\
(0.0264)\end{array}$ & $\begin{array}{l}0.0843^{* * *} \\
(0.0209)\end{array}$ & $\begin{array}{l}0.0649 * * \\
(0.0326)\end{array}$ \\
\hline Distance JFM & Distance to JFM forest in minutes & $\begin{array}{c}22.85^{* * *} \\
(2.035)\end{array}$ & $\begin{array}{c}69.05^{* * *} \\
(5.358)\end{array}$ & $\begin{array}{c}-45.62^{* * *} \\
(5.506)\end{array}$ \\
\hline Distance Other Forest & Distance to non-JFM forest in minutes & $\begin{array}{c}194.1^{* * *} \\
(6.294)\end{array}$ & $\begin{array}{c}137.6^{* * *} \\
(8.002)\end{array}$ & $\begin{array}{c}54.02^{* * *} \\
(10.03)\end{array}$ \\
\hline Male-Headed Household & Binary $(=1$, if HH headed by male) & $\begin{array}{l}0.922^{* * *} \\
(0.0201)\end{array}$ & $\begin{array}{l}0.949 * * * \\
(0.0165)\end{array}$ & $\begin{array}{c}-0.0271 \\
(0.0249)\end{array}$ \\
\hline Livestock Holdings (Before JFM) & $\begin{array}{l}\text { Livestock holdings in Tropical Livestock } \\
\text { Units before JFM implementation }\end{array}$ & $\begin{array}{c}4.088^{* * *} \\
(0.288)\end{array}$ & $\begin{array}{c}3.377^{* * *} \\
(0.208)\end{array}$ & $\begin{array}{c}0.618^{*} \\
(0.345)\end{array}$ \\
\hline Other Collective Action Participation & $\begin{array}{l}\text { HH participated in collective action before } \\
\text { the programs }\end{array}$ & $\begin{array}{l}0.156^{* * *} \\
(0.0272)\end{array}$ & $\begin{array}{c}0.0562^{* * *} \\
(0.0173)\end{array}$ & $\begin{array}{c}0.0971^{* * *} \\
(0.0310)\end{array}$ \\
\hline Household Head Age & Age of HH head & $\begin{array}{c}36.67^{* * *} \\
(0.985)\end{array}$ & $\begin{array}{c}35.80^{* * *} \\
(1.075)\end{array}$ & $\begin{array}{c}0.672 \\
(1.438)\end{array}$ \\
\hline Household Head Education & Education of HH head in years & $\begin{array}{c}2.218^{* * *} \\
(0.212)\end{array}$ & $\begin{array}{c}2.478^{* * *} \\
(0.241)\end{array}$ & $\begin{array}{l}-0.235 \\
(0.319)\end{array}$ \\
\hline Household Males 16-64 & Number of $\mathrm{HH}$ males of working age & $\begin{array}{l}1.285^{* * *} \\
(0.0490)\end{array}$ & $\begin{array}{l}1.264^{* * *} \\
(0.0439)\end{array}$ & $\begin{array}{c}0.00 \\
(0.0638)\end{array}$ \\
\hline Household Females 16-64 & Number of HH females of working age & $\begin{array}{l}1.352^{* * *} \\
(0.0504)\end{array}$ & $\begin{array}{l}1.152^{* * *} \\
(0.0402)\end{array}$ & $\begin{array}{l}0.177^{* * *} \\
(0.0626)\end{array}$ \\
\hline
\end{tabular}




\begin{tabular}{|c|c|c|c|c|}
\hline Off-farm Labor (Before JFM) & $\begin{array}{l}\text { Off-farm labor market participation before } \\
\text { JFM implementation }\end{array}$ & $\begin{array}{l}0.123^{* * *} \\
(0.0246)\end{array}$ & $\begin{array}{c}0.0730^{* * *} \\
(0.0196)\end{array}$ & $\begin{array}{c}0.0595^{*} \\
(0.0309)\end{array}$ \\
\hline Distance Extension & Distance to extension office in minutes & $\begin{array}{c}38.20^{* * *} \\
(3.857)\end{array}$ & $\begin{array}{c}52.40^{* * *} \\
(4.960)\end{array}$ & $\begin{array}{c}-14.13^{* *} \\
(6.015)\end{array}$ \\
\hline Distance Road & Distance to nearest road in minutes & $\begin{array}{c}23.00^{* * *} \\
(1.923)\end{array}$ & $\begin{array}{c}33.38^{* * *} \\
(2.840)\end{array}$ & $\begin{array}{l}-9.750^{* * *} \\
(3.308)\end{array}$ \\
\hline Distance Town & Distance to town in minutes & $\begin{array}{c}69.02^{* * *} \\
(3.488)\end{array}$ & $\begin{array}{c}72.67^{* * *} \\
(2.831)\end{array}$ & $\begin{array}{l}-4.404 \\
(4.381)\end{array}$ \\
\hline Menja & $\begin{array}{l}\text { Binary }(=1 \text {, if village includes someone from } \\
\text { Menja tribe) }\end{array}$ & $\begin{array}{l}0.788^{* * *} \\
(0.0307)\end{array}$ & $\begin{array}{l}0.416^{* * *} \\
(0.0370)\end{array}$ & $\begin{array}{l}0.379 * * * \\
(0.0471)\end{array}$ \\
\hline Menjahsz & $\begin{array}{l}\text { Total number of Menjas households } \\
\text { in the village }\end{array}$ & 34.25 & 67.986 & $\begin{array}{l}-33.736 \\
(3.361)\end{array}$ \\
\hline Mdensity & Menja households, $\%$ in village & 24.8 & 52.9 & $\begin{array}{c}-28.1 \\
(0.0324)\end{array}$ \\
\hline villhhsz & Number of households in a village & $\begin{array}{c}305.4324 \\
(13.686)\end{array}$ & $\begin{array}{l}260.093 \\
(13.478)\end{array}$ & $\begin{array}{l}45.339 * * \\
(19.2123)\end{array}$ \\
\hline vpopsze & Village population size & $\begin{array}{l}2588.438 \\
(31.684)\end{array}$ & $\begin{array}{c}1510.031 \\
(101.6739)\end{array}$ & $\begin{array}{c}-1078.406^{* * *} \\
(117.5137)\end{array}$ \\
\hline Alternative Forest Available & $\begin{array}{l}\text { Binary ( }=1 \text {, if } \mathrm{HH} \text { has access to alternative } \\
\text { forest) }\end{array}$ & $\begin{array}{l}0.240^{* * *} \\
(0.0320)\end{array}$ & $\begin{array}{l}0.483^{* * *} \\
(0.0376)\end{array}$ & $\begin{array}{l}-0.237^{* * *} \\
(0.0485)\end{array}$ \\
\hline Observations & & 179 & 178 & 377 \\
\hline
\end{tabular}

Source: Adapted from Gelo and Koch (2014) 
(Table 3).

Table 3. JFM Participation and Marginal Effects Estimates of Logit model

\begin{tabular}{lrcrr}
\hline \multirow{2}{*}{ Variable } & All households & \multicolumn{3}{c}{ Eligible households } \\
\cline { 2 - 3 } & Coefficient & Marginal effect & Coefficient marginal effect \\
\hline Distance to JFM Forest in Minutes & $-0.028^{* * *}$ & $-0.0069^{* * *}$ & $-0.0171^{* *}$ & $-0.0034^{* *}$ \\
& $(0.0063)$ & $(0.00150)$ & $(0.0081)$ & $(0.00165)$ \\
Other forest available & $-0.981^{* * *}$ & $-0.233^{* * *}$ & $-1.101^{* * *}$ & $-0.236^{* * *}$ \\
& $(0.285)$ & $(0.0647)$ & $(0.353)$ & $(0.0769)$ \\
Male-headed household & -0.261 & -0.0650 & 0.425 & 0.0910 \\
& $(0.611)$ & $(0.153)$ & $(0.611)$ & $(0.138)$ \\
Livestock Holdings Before JFM & $0.125^{* * *}$ & $0.0308^{* * *}$ & $0.144^{* *}$ & $0.0287^{* *}$ \\
& $(0.0451)$ & $(0.0111)$ & $(0.0589)$ & $(0.0116)$ \\
Collective action experience before JFM & $1.379^{* * *}$ & $0.324^{* * *}$ & $1.022^{*}$ & $0.169^{* *}$ \\
& $(0.486)$ & $(0.0986)$ & $(0.566)$ & $(0.0765)$ \\
Age of Household Head before JFM & -0.0102 & -0.00253 & -0.0123 & -0.00245 \\
& $(0.0113)$ & $(0.00279)$ & $(0.0137)$ & $(0.00272)$ \\
Education of Household Head before JFM & 0.0198 & 0.00488 & -0.00044 & $-8.91 \mathrm{e}-05$ \\
& $(0.0494)$ & $(0.0122)$ & $(0.0702)$ & $(0.0140)$ \\
Household males 16-64 & -0.330 & -0.0814 & -0.501 & -0.0999 \\
& $(0.243)$ & $(0.0600)$ & $(0.339)$ & $(0.0679)$ \\
Household females 16-64 & $0.830^{* * *}$ & $0.205^{* * *}$ & $1.436^{* * *}$ & $0.286^{* * *}$ \\
Off-farm labor (before JFM) & $(0.273)$ & $(0.0671)$ & $(0.386)$ & $(0.0729)$ \\
& 0.805 & $0.198^{*}$ & $1.524^{*}$ & $0.218^{* * *}$ \\
Distance to Rural Extension Office in Minutes & $(0.498)$ & $(0.117)$ & $(0.825)$ & $(0.0728)$ \\
& $-0.0049^{*}$ & $-0.00122^{*}$ & $-0.0050^{*}$ & $-0.00101^{*}$ \\
Distance to Road in Minutes & $(0.0025)$ & $(0.000639)$ & $(0.0030)$ & $(0.00061)$ \\
& $-0.0089^{*}$ & $-0.00222^{*}$ & $-0.0127^{* *}$ & $-0.0025^{* *}$ \\
Distance to Town in Minutes & $(0.0047)$ & $(0.00118)$ & $(0.0049)$ & $(0.00099)$ \\
Menja & -0.00381 & -0.000941 & -0.00039 & $-7.90 \mathrm{e}-05$ \\
Constant & $(0.0032)$ & $(0.000806)$ & $(0.0038)$ & $(0.00076)$ \\
& $1.393^{* * *}$ & $0.325^{* * *}$ & & \\
\hline
\end{tabular}

Source: Adapted from Gelo and Koch (2014)

\section{The impact of JFM participation on welfare}

In this section, we present results of JFM welfare impacts from different empirical strategies. We start with presentation of the treatment effects estimates of OLS and PSM (see Table 5). An estimate of the OLS estimator suggests that JFM participation has increased welfare benefits by ETB353* (i.e., about 20\%). However, when we limit the analysis to the subsample of households 
in villages selected for the JFM program (hereafter, JFM eligible households), instead of the entire sample, the treatment effects turn out to be zero. This disparity arises either from selection bias within eligible villages (with lower income households selecting into JFM) or spillovers that result in increased consumption expenditures of non-participating households in the same villages.

Before turning to the results from the matching estimator, the underlying premises of matching confoundedness and overlap - must be considered. Figure 1 alludes to an appropriate magnitude of overlap. Although there are propensity scores that are too close to either zero or one, where overlap is a problem, the majority of participants and non-participants have similar estimated propensity scores.

Because a wide range of matches is considered in the analysis, the match quality across these different algorithms deserves attention. The final choice of the matching algorithm is potentially guided by a broad set of criteria, primarily concerned with the quality of the match. ${ }^{23}$

\footnotetext{
${ }^{23} \mathrm{We}$ assessed matching quality against a broader set of measures. In the interest of brevity, we refer readers to Sianesi (2004) and (Caliendo and Kopeinig, 2008) for better exposition of matching quality assessment. Table 4 provides information related to the quality of kernel and nearest neighbor $(\mathrm{NN})$ matching algorithms. According to the results reported in Table 4, NN (4) and NN (5) with replacement performed the best, followed by kernel (0.005), on the basis of all the matching quality indicators: mean bias, variance, pseudo $R^{2}$ and LR $c h i^{2}$ values after matching. Specifically, nearest neighbor algorithms of 4 and 5 matches per observation, i.e., NN(4) and NN (5), have relatively lower pseudo $R^{2}$ and the highest p-values to support the null hypothesis of joint insignificance after matching.
} 


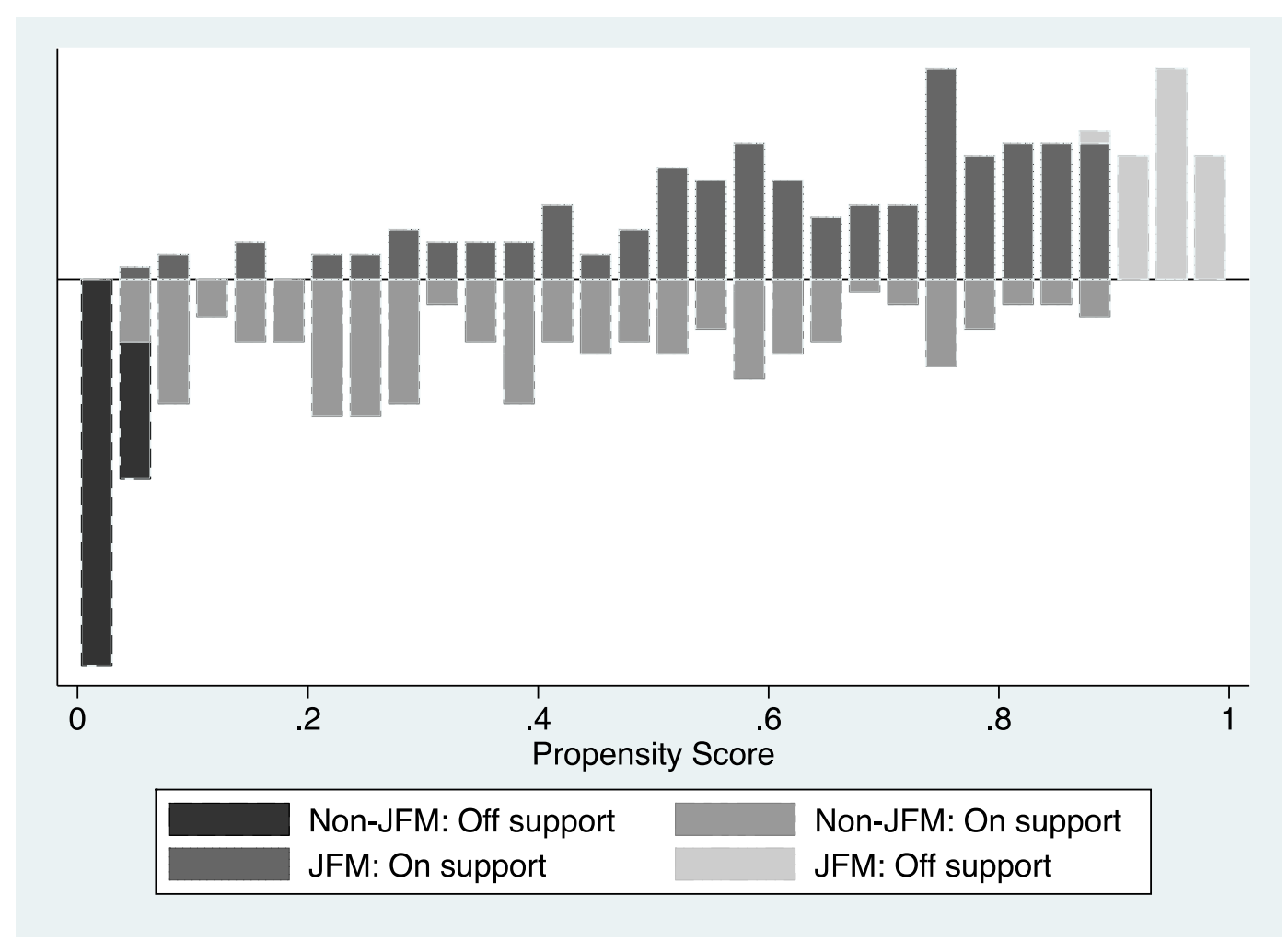

Figure 1. Histogram of Propensity Scores

Our PSM treatment effect analysis was, thus, based on NN(4) and NN(5) matching algorithms. Following Abadie and Imbens (2011), we implemented a bias-corrected NN estimator, as opposed to a simple matching estimator. ${ }^{24}$ The analysis shows that, for the best matches, $\mathrm{NN}(4)$ and $\mathrm{NN}(5)$ matching, the program's average welfare impact on the program participants is estimated to range from ETB354 to ETB359 and each of the estimates is significantly different from zero. However, when we limit the analysis to the subsample of JFM eligible households, these estimates rise to ETB446 and ETB387, respectively.

\footnotetext{
${ }^{24}$ Abadie et al. (2011) showed that simple matching estimators include a conditional bias term, which may not vanish at a rate faster than root- $\mathrm{N}$ and consequently is not root- $\mathrm{N}$ consistent. They also established that, even after removing the conditional bias, simple matching estimators with a fixed number of matches do not reach the semiparametric efficiency bound for average treatment effects, despite their small efficiency loss. These authors, instead, developed a bias-correction matching estimator that removes the conditional bias asymptotically, making matching estimators root- $\mathrm{N}$ consistent.
} 
The ensuing analyses were preceded by testing endogeneity of participation (the treatment variable) and whether it arises from essential heterogeneity. The Durbin-Wu-Hausman (DWH) statistic rejected the null hypothesis of exogeneity. The test for essential heterogeneity based on Heckman et al. (2006) supported the null hypothesis of no essential heterogeneity (idiosyncratic sorting gain) in our data set. ${ }^{25}$ This indicates that standard IV methods can identify treatment effects of the program. Table 6 presents average treatment effect estimates of various IV specifications. The analysis shows that average treatment on the treated (ATT) from the LIV specification is estimated to be ETB585 (see the first column of Table 6).

Table 4. Propensity score matching quality test

\begin{tabular}{lllllll}
\hline Performance & Kernel(0.005) & Kernel(0.005) & NN(4) & NN(4) & NN(5) & NN(5) \\
indicator & before & after & before & after & before & after \\
ASB & 30.6 & 15.0 & 30.6 & 9.9 & 30.6 & 5.7 \\
Variance & 801.33 & 87.99 & 801.33 & 71.09 & 801.33 & 12.6 \\
Pseudo $R^{2}$ & 0.325 & 0.08 & 0.325 & 0.056 & 0.325 & 0.012 \\
LR $c h i^{2}$ & 157.09 & 17.85 & 157.09 & 4.02 & 157.09 & 4.55 \\
p> ch & 0.00 & 0.21 & 0.00 & 0.99 & 0.00 & 0.99 \\
Balance test & & 12 & & 14 & & 14 \\
\hline
\end{tabular}

Table 5. Treatment Effects from PSM and OLS Specifications

\begin{tabular}{lcccccc}
\hline & \multicolumn{2}{c}{ All households } & & \multicolumn{2}{c}{ JFM eligible households } \\
Variables & OLS & PSM-NN(4) & PSM-NN(5) & OLS & PSM-NN(4) & PSM-NN(5) \\
\hline & & & & & & \\
Partcp & $353.4^{*}$ & $354.19^{*}$ & $358.66^{* * *}$ & -332.65 & $446.13^{* * *}$ & $386.560^{* * *}$ \\
& $(1.956)$ & $(106.39)$ & $(105.51)$ & $(477.88)$ & $(145.52)$ & $(145.18)$ \\
& & & & & \\
R-squared & 0.27 & & & & \\
Observations & 365 & 352 & 352 & 172 & & 211 \\
\hline Standard errors in parentheses ${ }^{* * *} \mathrm{p}<0.01,{ }^{* *} \mathrm{p}<0.05,{ }^{*} \mathrm{p}<0.1$ &
\end{tabular}

\footnotetext{
${ }^{25}$ Joint tests for quadratic, cubic and quartic terms of propensity score polynomials are respectively L.R $c h^{2}=1.39$, $\mathrm{p}=0.498, \mathrm{~L} . \mathrm{R} c h^{2}=6.07, \mathrm{p}=0.108$, and L.R $c h^{2}=4.48, \mathrm{p}=0.345$.
} 
Table 6. Treatment effects from alternative IV method specifications

\begin{tabular}{|c|c|c|c|c|c|c|c|c|}
\hline \multirow[b]{2}{*}{ Variables } & \multicolumn{2}{|c|}{ Semi-parametric specifications: } & \multirow[b]{2}{*}{ Genlnst } & \multirow[b]{2}{*}{ GenExtInst } & \multicolumn{3}{|c|}{ Traditional 2SLS Models } & \multirow[b]{2}{*}{ Model IV } \\
\hline & LIV & IV-LATE & & & Model I & Model II & Model III & \\
\hline \multirow[t]{2}{*}{ Partcp } & $585.39^{* *}$ & $548.45^{\star \star \star}$ & $400.9^{*}$ & $391.9^{\star \star}$ & $398.75^{\star *}$ & $463.52^{* *}$ & $552.07^{* *}$ & $578.2^{*}$ \\
\hline & $(243.19)$ & $(182.57)$ & $(222.9)$ & $(161.0)$ & $(167.24)$ & $(263.52)$ & $(252.60)$ & $(297.7)$ \\
\hline \multirow[t]{2}{*}{ offrma } & -350.58 & & 94.12 & 90.26 & 113.39 & 134.01 & 126.9 & 119.6 \\
\hline & $(371.55)$ & & $(171.3)$ & $(169.2)$ & $(141.57)$ & $(167.15)$ & $(165.3)$ & $(163.7)$ \\
\hline \multirow[t]{2}{*}{ Indsza } & -15.63 & & & & 29.34 & 54.295 & 55.32 & 56.36 \\
\hline & $(70.73)$ & & & & $(31.01)$ & $(38.92)$ & $(39.27)$ & $(39.60)$ \\
\hline \multirow[t]{2}{*}{ agea } & -4.42 & & & & -4.08 & -2.104 & -2.221 & -2.340 \\
\hline & $(8.15)$ & & & & (3.52) & (3.88) & (3.909) & (3.926) \\
\hline \multirow[t]{2}{*}{ hhsize } & $-130.46^{* *}$ & & $-173.1^{\star \star \star}$ & $-173.0^{* * *}$ & $-171.88^{* * *}$ & $-177.67^{\star \star *}$ & -47.89 & -31.16 \\
\hline & (59.33) & & (25.57) & $(25.44)$ & (22.70) & (26.75) & (211.7) & $(214.4)$ \\
\hline \multirow[t]{2}{*}{ wealth } & 25.67 & & $346.5^{* *}$ & $344.1^{* *}$ & $200.58^{* *}$ & $185.37^{*}$ & $-178.1^{* * *}$ & $-178.5^{* * *}$ \\
\hline & $(190.61)$ & & (136.1) & (135.2) & $(104.81)$ & (114.73) & (26.72) & (26.47) \\
\hline \multirow[t]{2}{*}{ hhdstwnmin } & -5.59 & & $-3.152^{* * *}$ & $-3.188^{* * *}$ & -1.33 & $-3.68^{* *}$ & 183.9 & 182.4 \\
\hline & $(4.48)$ & & $(1.180)$ & (1.167) & $(0.930)$ & $(1.174)$ & (115.5) & $(117.0)$ \\
\hline \multirow[t]{2}{*}{ hhdstroadmin } & 6.82 & & -1.787 & -1.832 & -1.40 & -0.49 & $-3.805^{\star * *}$ & $-3.926^{\star * *}$ \\
\hline & (3.49) & & $(2.160)$ & $(2.160)$ & $(1.50)$ & $(1.72)$ & $(1.159)$ & $(1.167)$ \\
\hline \multirow[t]{2}{*}{ Tlua } & $81.67^{\star *}$ & & 33.09 & 32.74 & $47.54^{* \star *}$ & $43.43^{* * *}$ & -0.406 & -0.316 \\
\hline & $(40.70)$ & & $(20.60)$ & $(20.00)$ & (17.09) & (18.23) & $(1.748)$ & $(1.737)$ \\
\hline \multirow[t]{2}{*}{ edumax } & $35.95^{\star *}$ & & -60.10 & & $33.43^{* * *}$ & 26.105 & $43.56^{* *}$ & $43.69^{* *}$ \\
\hline & (31.77) & & (37.82) & & (14.95) & (17.43) & (18.19) & (18.11) \\
\hline \multirow[t]{2}{*}{ sex } & -101.97 & & -200.25 & & -50.47 & -64.23 & -192.8 & $-233.3^{*}$ \\
\hline & (495.61) & & (476.38) & & (190.1) & (213.54) & (128.0) & (141.2) \\
\hline \multirow[t]{2}{*}{ vpopsze } & -0.176 & & $-0.452^{* \star \star}$ & $-0.454^{* * *}$ & $-0.123^{\star \star \star}$ & $-0.49 * *$ & $-0.548^{* * *}$ & $-0.602^{* * *}$ \\
\hline & $(0.14)$ & & $(0.106)$ & $(0.105)$ & $(0.0382)$ & $(0.210)$ & $(0.200)$ & $(0.215)$ \\
\hline Constant & & & $\begin{array}{c}2,805^{\star * *} \\
(437.9)\end{array}$ & $\begin{array}{c}2,822^{* \star *} \\
(4299)\end{array}$ & $\begin{array}{c}2,874^{\star \star *} \\
(2216)\end{array}$ & $\begin{array}{c}2,700.94^{* * *} \\
(355.06)\end{array}$ & $\begin{array}{c}2,872^{\star \star *} \\
(2216)\end{array}$ & $\begin{array}{c}2,871^{\star * *} \\
(2203)\end{array}$ \\
\hline Observations & & & 280 & 280 & 359 & 359 & 370 & 359 \\
\hline R-squared & & & 0.297 & 0.297 & 0.244 & 0.275 & 0.243 & 0.247 \\
\hline
\end{tabular}

Robust standard errors in parentheses. $* * * \mathrm{p}<0.01, * * \mathrm{p}<0.05, * \mathrm{p}<0.1$ 
In light of the evidence of no essential heterogeneity of treatment effects, we extended the analysis to standard IV methods. In the initial analysis, treatment effects were examined based on an intention to treat strategy, whereby Menjas prevalence was used as an instrument for participation. The Local Average Treatment Effect (LATE) from the non-parametric specification of this model is estimated to be ETB548 (see the second column of Table 6). This estimate falls within the $95 \%$ interval of the LIV estimate. Note also that the LATE is the average treatment effect for only $44 \%$ of program participants, compared to the LIV estimate of ATT, which applies to the entire sample.

In the interest of testing the exogeneity (validity) of instruments, we further specified alternative 2SLS models of multiple instruments. We first analysed the treatment effect using heteroskedasticity-based instrumentation (internally generated instruments) of Lewbel (2012). Within this context, we implemented the models that involved only internally generated instruments, denoted GenInst, and one in which the generated instruments are used to supplement our initial instrument of Menjas prevalence, denoted GenExtInst. In a follow-up analysis, the treatment effects were examined based on the three models of external instruments, with each of the models corresponding to a particular combination of instrumental variables. In effect, Model I, which is an intention to treat strategy, combines eligibility variables associated with Menjas prevalence - whether or not Menjas were present in the village, the density of the Menjas population in the village, and the total number of Menjas households in the village - and uses these as instruments for participation. Model II uses a combination of Menjas prevalence and the number of ethnic groups (a measure of forest users' heterogeneity in the villages selected for JFM intervention) to instrument for participation. In Model III, the treatment effect was 
examined based on a combination of Menjas prevalence and household level factors, such as the distance to the JFM forest, the availability of an alternative forest, and household pre-program experience with collective action programs, to instrument for participation. In Model IV, we considered only household level, as opposed to village level, baseline covariates (i.e., they preceded our outcomes variables by many years), as instruments.

Table 7. 2SLS Estimates of model with different combinations of IVs

\begin{tabular}{|c|c|c|c|c|c|c|}
\hline $\begin{array}{l}\text { Variables } \\
\text { partcp }\end{array}$ & $\begin{array}{c}\text { Genlnst } \\
400.9^{*} \\
(222.9)\end{array}$ & $\begin{array}{c}\text { GenExtlnst } \\
391.9^{* *} \\
(161.0)\end{array}$ & $\begin{array}{c}\text { Model I } \\
398.75^{\star *} \\
(167.24)\end{array}$ & $\begin{array}{l}\text { Model II } \\
463.52^{\star *} \\
(263.52)\end{array}$ & $\begin{array}{l}\text { Model III } \\
552.07^{\star *} \\
(252.60)\end{array}$ & $\begin{array}{c}\text { Model IV } \\
578.2^{*} \\
(297.7)\end{array}$ \\
\hline R-squared & 0.297 & 0.297 & 0.340 & 0.866 & 0.855 & 0.801 \\
\hline menja & & & $\begin{array}{c}0.660^{\star \star \star} \\
(0.094)\end{array}$ & $\begin{array}{c}0.212^{\star \star \star} \\
(0.057)\end{array}$ & $\begin{array}{l}0.432^{\star \star \star} \\
(0.06)\end{array}$ & \\
\hline Ethnic & & & & $\begin{array}{l}-0.046 \\
(0.06)\end{array}$ & & \\
\hline menjadensity & & & $\begin{array}{c}-0.658^{\star *} \\
(0.237)\end{array}$ & & & \\
\hline menghhsz & & & $\begin{array}{c}0.0054^{* * *} \\
(0.034)\end{array}$ & & & \\
\hline othpartcp & & & & & $\begin{array}{c}0.033 \\
(0.026)\end{array}$ & $\begin{array}{c}0.116 \\
(0.029)\end{array}$ \\
\hline dstpfm & & & & & $\begin{array}{c}-0.0051^{* * *} \\
(0.0033)\end{array}$ & $\begin{array}{c}-0.0021^{* * *} \\
(0.003)\end{array}$ \\
\hline othfrst & & & & & $\begin{array}{r}-0.0487 \\
(0.030)\end{array}$ & $\begin{array}{c}-0.0282 \\
(0.031)\end{array}$ \\
\hline R-squared & & & 0.838 & & 0.0 .855 & 0.795 \\
\hline Observations & 280 & 280 & 359 & 359 & 359 & 359 \\
\hline \multicolumn{7}{|c|}{ 2SLS Performance } \\
\hline KP LM & $31.2^{* *}$ & $70.08^{\star * *}$ & $128.70^{\star * *}$ & $79.72^{* * *}$ & $66.07^{* * *}$ & $40.88^{\star * *}$ \\
\hline CD Wald & 23.68 & 56.86 & 185.93 & 132.43 & 56.39 & 29.83 \\
\hline SY $10 \%$ & 11.39 & 11.46 & 24.58 & 19.93 & 10.27 & 9.08 \\
\hline AR Wald & $58.5^{\star *}$ & $56.86^{\star *}$ & $2.45^{\star *}$ & 5.49 ** & $10.14^{\star *}$ & $9.41^{* *}$ \\
\hline Hansen J & 6.70 & 6.656 & 1.291 & 1.460 & 4.334 & 3.621 \\
\hline
\end{tabular}

Robust standard errors in parentheses. $* * * p<0.01, * * \mathrm{p}<0.05, * \mathrm{p}<0.1$

The top panel of Table 7 contains the estimated treatment effects and the $R^{2}$ from all the 2SLS models, while the second panel contains the estimates of the different excluded variables on participation, along with the $R^{2}$ from the first stage. In the third and final panel, a variety of performance statistics of the 2SLS model are presented, including Kleibergen and Paap's (2006) LM statistic of model identification (KP LM); Cragg and Donald's (1993) Wald statistic (CD 
Wald); Stock and Yogo's (2005) 10\% critical value (SY 10\%) of weak instrumentation, which is applied to the CD Wald value; the Anderson and Rubin (1949) Wald statistic for the hypothesis that the treatment effect is both insignificant and exogenously identified by the instruments; and Hansen's J-statistic of over-identification, for cases when more than one instrument is included. In all models, standard errors are clustered at the village level to control for potential correlation within the villages. In all models, the Hansen/Sargan test cannot reject the hypothesis that instruments are correctly excluded from the estimated equation, i.e., excluded instruments are valid instruments. Moreover, instruments were relevant in all models, given the Stock-Yogo 10\% critical value, and, in all models, KP LM statistics reject the null hypothesis of underidentification. However, because these test statistics involve joint tests of irrelevant regressors and appropriate over-identifying restrictions, the evidence may not be so promising. Thus, we additionally tested for validity and relevance of each instrument, within each model, by carrying out orthogonality and redundancy tests, respectively. The test results suggested that GenInst, GenExtInst and Model I performed best and, as such, our discussion of treatment effects is based on the estimates of these models.

According to the t-statistics, treatment effects are estimated to be positive and significant in all of the reported analyses. The estimated treatment effects in our preferred models ranged between ETB392 and ETB401, with standard errors in the regions of ETB161 and ETB223 respectively, such that a 95\% confidence interval of the treatment effect falls between ETB127 and ETB768. Given that the mean per capita consumption of participants is ETB1732, as noted above, the program has increased welfare by either as little as $7 \%$ or by as much as $44 \%$, with an average 
increase of approximately $26 \%$. Not only are these treatment effects statistically significant, they are economically significant as well.

Finally, our analysis based on a multi-valued treatment effect model shows that the program's welfare effect is largely attributable to the marketing component of the program. Specifically, we found that the average FUC household consumes ETB456 more than the average FUG program household and ETB538.042 more than the average baseline (non-program) household. However, the average FUG household consumes only ETB82.02 more compared to non-program average consumption (Figure 2).

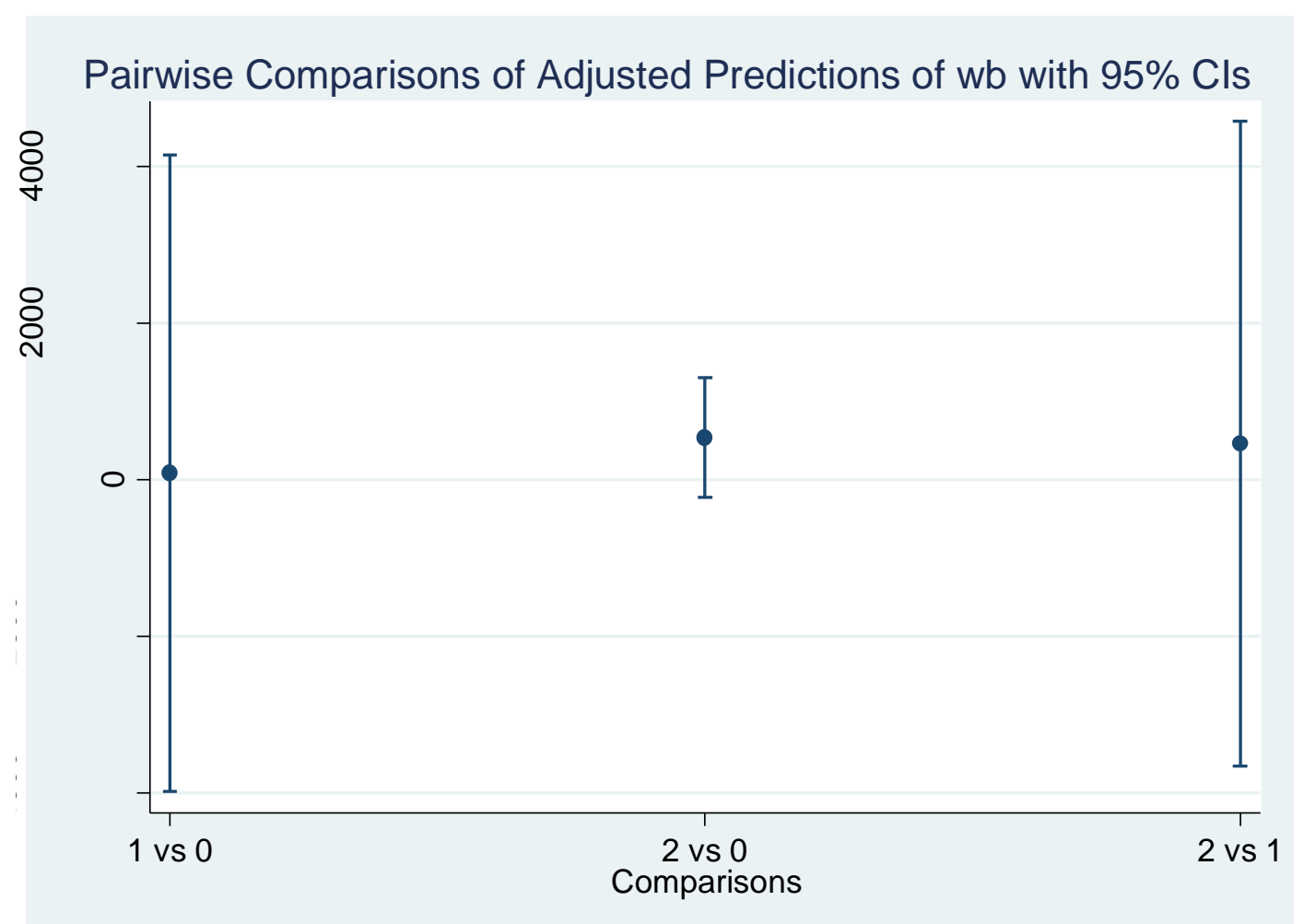

Figure2. Multi-Valued Treatment Efects (wb is a multi-treatment variable)

There is handful of prior evidence that makes a case for these results. Related studies in the 
Bonga region confirmed that FUC has improved farmers' access to new, fair and sustainable market opportunities, enabling them to sell their products (coffee, honey, spices) at better prices. For example, program farmers, through the FUC, sell forest coffee at $87 \%$ higher prices than do non-program farmers (Shumeta et al., 2012). Likewise, they sell honey at 70\% higher prices compared to non-program farmers (SOS SAHEL, 2007). These price premiums are attributed to savings on transaction costs (searching, bargaining, etc.) as well as added value accruing from processing, at least in the case of honey (Figure 3).

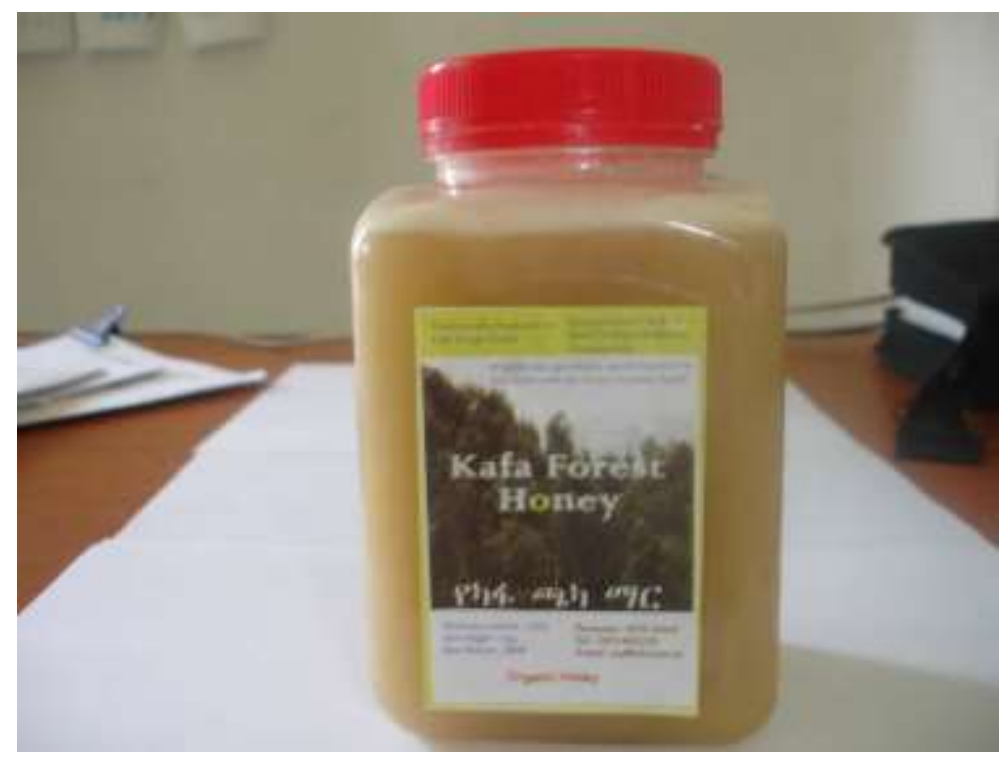

Figure 3. Processed honey product (SOS Sahel, 2007)

Moreover, a recent study by Gelo and Koch (2014) has ascertained that the JFM program under consideration raised annual per capita NTFP revenue by ETB 252-277, which is an increase in excess of $100 \%$ of the annual per capita NTFP revenue of ETB 235 for non-program farmers. However, as this study lumped FUC and non-FUC program farmers into one treatment group, it is not clear whether the greater NTFP revenue effect was attributable to increased labor productivity (higher quantity) or higher prices of NTFPs. In fact, there is reason to believe that 
the program has raised labor productivity in NTFP extraction. Forest inventory studies by Bekele and Bekele (2005), Limenih and Bekele (2008) and Gobeze et al. (2009) showed that forest regeneration and biomass production, including that of undergrowth and NTFP, are higher in program forests than in non-program forests. Thus, increased forest stock, as a result of greater regeneration, could bolster productivity of labor deployed for the collection of forest products, including NTFPs, by shortening the time required for the collection. However, within program households, descriptive statistics analysis of our data shows a statistically significant simple mean difference of per capita NTFP revenue, amounting to ETB189.25, between FUC and nonFUC program households, corroborating our finding that the price effect of the program on household welfare exceeds the productivity effect.

Overall, the results lend support to Dasgupta (2006) and are consistent with the conjecture proposed by Wunder (2001) that NTFP marketing offers sizeable welfare gains. Nonetheless, in light of the small number of FUG members in our sample (47 households) and the conditional independence assumption (CIA) of the multi-valued treatment effect estimator applied here, these results must be interpreted with that caveat.

In addition to the participation effects previously discussed, a number of other variables are found to be important determinants of per capita consumption expenditure. As would be expected, simply from the definition of per capita consumption expenditure, larger households spend approximately ETB172 less per household member. Households with a corrugated roof (an indicator of relative wealth) and families with more livestock consume significantly more per capita. Households with poorer access to markets, i.e., those located farther from roads or towns, 
and households residing in villages with higher population consume significantly less, whereas education in the household (the highest level of education attained by any member of the household) is associated with significantly higher per capita expenditure.

\section{Welfare Distribution Analysis}

Table 8 presents the results of Oaxaca decomposition of the welfare gap between poor and nonpoor subsamples. As expected, the total per capita expenditure gap is positive and statistically significant. From the second column of the table, we observe that inequality in average household size and access to markets (distances to market) significantly contribute to the raw (total) welfare gap between the poor and non-poor. Moreover, to the extent that the differences in coefficients of livestock holding, distance to road, education and program participation are statistically significant, the welfare gap is also attributable to the differential effects of these covariates on welfare across the groups. In particular, the analysis shows that participation in the program earns the average non-poor participant ETB121 (i.e., about $7 \%$ of baseline welfare or $27 \%$ of ATT reported above) higher welfare gain compared to the average poor participant. ${ }^{26}$

This supports our hypothesis that the welfare effects of the program vary across poor and nonpoor program participants. An important observation emerging from this result is that participation in the type of JFM we studied reinforces welfare inequality against poor participants.

An explanation for distributive bias in JFM participation is in order. Earnings from JFM participation, which occur throughout the year, meet liquidity demands for seasonal agricultural

\footnotetext{
${ }^{26}$ Our quantile treatment effect (QTE) evaluation, not reported here, showed that treatment effects corresponding to the bottom quantiles of welfare distribution are not statistically significant. This suggests that the lot of the poor was not necessarily worsened by the program.
} 
Table 8: IV-based Oaxaca welfare gap decomposition estimates

\begin{tabular}{|c|c|c|c|c|}
\hline \multicolumn{5}{|c|}{ Poverty class welfare gap } \\
\hline Variables & Differential & Endowments & Coefficients & Interaction \\
\hline partcp & & $\begin{array}{c}-89.99 \\
(97.34)\end{array}$ & $\begin{array}{l}121.6^{* *} \\
(56.55)\end{array}$ & $\begin{array}{c}89.99 \\
(97.34)\end{array}$ \\
\hline wealth & & $\begin{array}{l}-2.779 \\
(24.99)\end{array}$ & $\begin{array}{c}219.0 \\
(167.6)\end{array}$ & $\begin{array}{l}-9.083 \\
(81.55)\end{array}$ \\
\hline agea & & $\begin{array}{c}13.10 \\
(45.91)\end{array}$ & $\begin{array}{c}-3,979 \\
(5,436)\end{array}$ & $\begin{array}{c}715.3 \\
(1,063)\end{array}$ \\
\hline tlua & & $\begin{array}{c}2.100 \\
(48.54)\end{array}$ & $\begin{array}{c}1,823^{*} \\
(1,014)\end{array}$ & $\begin{array}{l}-13.19 \\
(304.9)\end{array}$ \\
\hline Indsza & & $\begin{array}{c}-16.48 \\
(43.92)\end{array}$ & $\begin{array}{c}2,003 \\
(2,871)\end{array}$ & $\begin{array}{l}-207.7 \\
(604.5)\end{array}$ \\
\hline hhsize & & $\begin{array}{c}-234.3^{\star *} \\
(105.9)\end{array}$ & $\begin{array}{c}2,058 \\
(4,393)\end{array}$ & $\begin{array}{l}-580.0 \\
(1,258)\end{array}$ \\
\hline hhdstroadmin & & $\begin{array}{l}-12.93 \\
(20.28)\end{array}$ & $\begin{array}{c}-2,820^{* *} \\
(1,341)\end{array}$ & $\begin{array}{c}692.3 \\
(913.0)\end{array}$ \\
\hline hhdstwnmin & & $\begin{array}{l}-106.7^{*} \\
(63.75)\end{array}$ & $\begin{array}{c}5,040 \\
(3,478)\end{array}$ & $\begin{array}{l}-1,271 \\
\end{array}$ \\
\hline edumax & & $\begin{array}{c}58.32 \\
(50.85)\end{array}$ & $\begin{array}{c}-4,575^{\star * *} \\
(1,035)\end{array}$ & $\begin{array}{c}914.2 \\
(682.4)\end{array}$ \\
\hline vpopsze & & $\begin{array}{l}-39.62 \\
(50.26)\end{array}$ & $\begin{array}{l}-1,250 \\
(2,011)\end{array}$ & $\begin{array}{c}392.9 \\
(680.9)\end{array}$ \\
\hline Total & & $\begin{array}{c}-425.8^{* \star *} \\
(164.9)\end{array}$ & $\begin{array}{l}-3,208^{*} \\
(1,893)\end{array}$ & $\begin{array}{c}732.4 \\
(1,899)\end{array}$ \\
\hline Prediction_1 & $\begin{array}{c}1,582^{* * *} \\
(71.49)\end{array}$ & & & \\
\hline Prediction_2 & $\begin{array}{c}4,483^{* * *} \\
(331.7)\end{array}$ & & & \\
\hline Difference & $\begin{array}{c}2,902^{* \star *} \\
(339.3)\end{array}$ & & & \\
\hline Constant & & & $\begin{array}{c}-2,202 \\
(1,529)\end{array}$ & \\
\hline Observations & 266 & 266 & 266 & 266 \\
\hline
\end{tabular}


production in the face of limited credit access. For example, proceeds from JFM participation may be used to purchase such inputs as fertilizer, improved seed, animal medicine and feed, which yield greater farm income, leading to greater consumption. However, the significance of this opportunity has to do with the level of the endowment of such productive assets as land, livestock, and physical assets, such as those used for, say, petty trade. For example, households with few or none of these productive assets (e.g., landless households), who are described as poor, may not stand to benefit from new investment opportunities made possible by greater income. Such differential income opportunities afforded by participation in JFM are likely to result in heterogeneous effects of JFM across poor and non-poor households. In short, existing inequality in asset holding determines the ability to gain benefits from program participation, implying an inequity reinforcing effect of the program. Second, if households perceive increased return to NTFP extraction as a secure and steady source of income over time and as an alternative that cushions shortfalls in farming income, they are likely to raise consumption due to lessened demand for precautionary saving. In fact, this depends on the extent of risk aversion of a household. Another explanation could be elite capture, in which more powerful participants (non-poor groups) steer resource use decisions in favor of themselves.

Our research is one of the few studies to consider differentiated JFM effects across income groups (poor and non-poor). Although we studied JFM bundled with marketing support, we do offer further support to Jumbe and Angelsen (2006), Adhikari (2005) and Agrawal (2001), who conclude that JFM is not equity enhancing. 


\section{Conclusion}

Previous literature on JFM impact evaluation provides mixed evidence on whether there are benefits to participants and hence whether this type of program affords incentives to protect forests. The majority of research findings show that the incentives for conservation associated with JFM are too small to offset the cost of forest use restrictions, and confirm that the poor bear the brunt of the cost. However, this literature has not ascertained whether JFM with alternative design options, for example, augmented with improved marketing of forest products, typically NTFP, has similar implications for welfare and equity outcomes. Motivated by these uncertainties, the present study set out to evaluate the welfare and distributive impacts of an augmented JFM program. The analysis was based on data collected in selected villages of the Gimbo district, southwestern Ethiopia. The causal link between program intervention and household welfare and welfare distribution was empirically investigated. The analysis revealed that this JFM intervention has raised the average welfare of participating households in the study villages. Identification based on observed controls, via OLS and PSM, yielded an average program effect of approximately ETB353 and ETB359 respectively. However, these estimates were generally lower than the program effects estimated via instrumental variables methods controlling for both observed and unobserved factors. Estimates from non-parametric instrumental variable specifications ranged from ETB548 to ETB585. However, 2SLS of multiple instruments models, which are our preferred models, yielded estimates ranging from ETB392 to ETB401, although estimates of both single IV models and matching identification strategies fall within the $95 \%$ confidence interval of treatment effects estimates of these IV models. 
The results from the analysis imply that the decentralization of natural forest management, when combined with market access support for NTFPs, has substantially raised participant household welfare, accounting for approximately one-quarter of total welfare. Moreover, the analysis showed that this welfare effect is largely driven by marketing incentives to use non-timber forest products. Although the benefits of the program are estimated to be large, our welfare gap decomposition analyses confirm that there is distributional bias of the program's effect, such that non-poor participants capture disproportionately greater welfare benefits than do their poor counterparts. This is likely to undermine the ability of these programs to further enhance rural development.

From a policy perspective, the evidence that augmenting JFM with improved marketing support for NTFP offers a greater welfare outcome underscores the importance of leveraging marketing linkages for forest products. This opens up alternative avenues to invest the public purse (as well as donor transfers such as REDD+ payments) in technical, institutional and infrastructural supports, thereby creating the incentives required for forest conservation. ${ }^{27}$ However, there is a need to consider the redesign of such programs to ensure that their impact will adequately reach the poor, so that they can serve as a dual instrument for forest conservation and rural development. One alternative is empowering poor household to participate in management decisions within the FUC structure in cases where local elites dominate and manipulate management decisions in their favor. ${ }^{28}$ Although the current benefit to the poor is non-existent,

\footnotetext{
${ }^{27}$ This can serve as one alternative use of payment for ecosystem services (PES) through REDD+ in order to save forests while ameliorating rural livelihoods.

${ }^{28}$ Note that Gelo et.al (2013) confirmed that distributional bias of these programs partly arises from elite capture.
} 
the possibility of even small increases in benefits from such measures may mean a significant contribution to their overall welfare in relative terms.

\section{References}

Abadie, A. 2003. Semi-parametric instrumental variable estimation of treatment response model. Journal of Econometrics 113: 231-263.

Abadie, A., and Imbens, G. W., 2011. Bias-Corrected Matching Estimators for Average Treatment Effects, Journal of Business \& Economic Statistics, American Statistical Association, 29: 1-11.

Abay, K., Kahsay. G., and Berhane, G. 2014. Social Networks and Factor Markets: Panel Data Evidence from Ethiopia, IFRO Working Paper No. 12, Department of Food and Resource Economics (IFRO) University of Copenhagen

Adhikari, B. 2005. Poverty, property rights and collective action: Understanding the distributive aspects of common property resources management. Environment and Development Economics 10: 7-31.

Agrawal, A., and C. Gibson. 1999. Enchantment and disenchantment: The role of community in natural resource conservation. World Development 27: 629-49.

Agrawal, A., and E. Ostrom. 2001. Collective action, property right and decentralization in resource use in India and Nepal. Politics and Society 4: 485-514.

Agrawal, B. 2001. Participatory exclusion, community forestry and gender: An analysis for South Asia and a conceptual framework. World Development 29: 1623-1648. 
Alderman, H. and C.H. Paxson. 1994. Do the poor insure? A synthesis of the literature on risk and consumption in developing countries', in D. Bacha (ed.), Economics in a Changing World, vol. 3, London: Macmillan, pp. 48-78.

Alemneh, D. 1990. "Peasants, environment, resettlement." In Ethiopia. Rural Development Options, edited by S. Pausewang, F. Cheru, S. Brüne, E. Chole. London, New Jersey: Zed Books, pp.174-86.

Ameha, A., O. Nielsen, and H. Larsen. 2014a. Impacts of access and benefit sharing on livelihoods and forest: Case of participatory forest management in Ethiopia. Ecological Economics 97: 162-171.

Ameha, A., H. Larsen, and M. Lemenih. 2014b. Participatory forest management in Ethiopia: Learning from pilot projects. Environmental Management 53: 838-854.

Anderson, T.W., and H. Rubin. 1949. Estimation of the parameters of a single equation in a complete system of stochastic equations. Annals of Mathematical Statistics 20: 46-63.

Antinori, C., 2005. Vertical integration in the forestry enterprises of Oaxaca. In: Barton- Bray, D., Merino-Perez, L., Barry, D. (Eds.), The Community Forests of Mexico: Managing for Sustainable Landscapes. University of Texas Press, Austin.

Baland, J.-M., and Platteau, J.-P. 1999. The ambiguous impact of inequality on local resource management. World Development, 27: 773-788.

Basu, B.A., J. Heckman, S. Navarro, and S. Urzua. 2007. Use of instrumental variables in the presence of heterogeneity and self-selection: An application to treatments of breast cancer patients. Health Economics 16: 1133-1157.

Berhane, G., Gardebroek, C., Moll, H.A., 2009. Risk-matching behaviour in microcredit group formation: evidence from northern Ethiopia. Agricultural Economics 40: 409-419. 
Bekele, M., and T. Bekele. 2005. Participatory forest management in Chilimo and Bonga, Ethiopia: An evaluation report. Farm Africa, Addis Ababa.

Bluffstone, R., E. Robinson, and A. Guthiga. 2013. REDD+ and community-controlled forests in low-income countries: Any hope for a linkage. Ecological Economics 87: 43-52.

Bluffstone, R. 2008. Does better common property forest management promote behavioural change? On farm tree planting in the Bolivian Andes. Environment and Development Economics 13: 137-170.

Caliendo, M., \& Kopeinig, S. (2008). Some practical guideline for the implementation of propensity score matching. Journal of Economic Surveys, 22, 31-72.

Caeyers, B., Dercon, S., 2012. Political connections and social networks in targeted transfer programs: evidence from rural Ethiopia. Economic Development and Cultural Change, 60, 639-675.

Chernozhukov, V., I. Fernández-Val, and B. Melly. 2013. Inference on counterfactual distributions. Econometrica 81: 2205-2268.

Cragg, J.G., and S.G. Donald. 1993. Testing identfiability and specification in instrumental variable models. Econometric Theory 9: 222-240.

Cobb-Clark, D.A., and T. Crossley. 2003. Econometrics for evaluation: An introduction to recent developments. The Economic Record 79: 491-511.

Dasgupta, P. 2006. Common property resources as development drivers: A study of fruit cooperative in Himachal Pradesh, India. SANDEE Working Paper No. 15-06.

Delacote, P. 2007. Agricultural expansion, forest products as safety nets and deforestation. Environment and Development Economics 12: 235-249.

Development Planning and Research Directorate. 2012. Ethiopia's progress towards eradicating poverty: an interim report on poverty analysis study (2010/11), Ministry of Finance and Economic Development of Ethiopia (MOFED), Addis Ababa 
Edmonds, E. 2002. Government-initiated community resources management and local resource extraction from Nepal's forests. Journal of Development Economics 68:89-115.

Fortin, N., T. Lemieux, and S. Firpo. 2010. Decomposition methods in economics." In Handbook of Labor Economics, Vol. 4A, edited by O. Ashenfelter and D. Card. Amsterdam: North-Holland, pp. 1-102.

Frölich, M. 2007. Nonparametric IV estimation of local average treatment effects with covariates. Journal of Econometrics 139: 35-75.

Gelo, D., and Koch, S. 2014. The impact of common property right forestry: Evidence from Ethiopian villages. World Development 64: 395-406.

Gelo, Dambala, Steven F. Koch and Edwin Muchapondwa (2013), Do the Poor Benefit from Devolution Policies? Evidence from Quantile Treatment Effect Evaluation of Joint Forest Management. Economic Research Southern Africa(ERSA) Working Paper No.400Gertler, P.J., J. Martinez, P. Premand, L.B. Rawlings, and C.M.J. Vermeersch. 2010. Impact Evaluation in Practice. Washington, D.C.: World Bank Publications.

Gobeze, T., Bekele, M., Lemenih, M., \& Kassa, H. 2009. Participatory forest management impacts on livelihood and forest status: The case of Bonga forest in Ethiopia. International Forestry Review, 11, 346-358.

Heckman, J., and E. Vytlacil. 2001. Policy relevant treatment effects. American Economic Review 91: 107-111.

Heckman, J.J., and S. Navarro-Lazano. 2004. Using matching, instrumental variables, and control functions to estimate economic choice models. Review of Economics and Statistics 86: 30-57.

Heckman, J., and E.J. Vytlacil. 2005. Structural equations, treatment effects and econometric policy evaluation. Econometrica 73: 669-738.

Heckman, J.J., S. Urzua, and E.J. Vytlacil. 2006. Understanding instrumental variables in models with essential heterogeneity. Review of Economics and Statistics 8: 389-432. 
Ichimura, H., and Todd, P. 2007. Implementing Nonparametric and Semi-parametric Estimators, Handbook of Econometrics, in: J.J. Heckman \& E.E. Leamer (ed.), Handbook of Econometrics, edition 1, volume 6, chapter 74 Elsevier.

Imbens, G., and J. Angrist. 1994. Identification and estimation of local average treatment effects. Econometrica 62: 467-475.

Jann, B., 2008. The Blinder-Oaxaca decomposition for linear regression models. The Stata Journal, 8: 453-479

Jumbe, C., and A. Angelsen. 2006. Do poor benefit from devolution? Evidence from Malawi comanagement programs. Land Economics 82: 562-581.

Kajembe, G. C., Nduwamungu, J., \& Luog, E. J. (2005). The impact of community-based forest management and joint management on the resource base and people's livelihood: Case studies from Tanzania, CAAS/PLASS occasional paper, Center for applied social sciences and program for land and Agrarian studies, University of Western Cape.

Kleibergen, F., and R. Paap. 2006. Generalized reduced rank tests using the singular value decomposition. Journal of Econometrics 133: 97-126.

Kubsa, A., A. Mariame, G. Amante, H.J. Lipp, and T. Tadesse. 2003. WAJIB: An alternative forest conservation approach for Ethiopia's forests. XII World Forestry Congress, Quebec, Canada.

Kumar, S. 2002. Does participation in common pool resource management help the poor? A social-cost-benefit analysis of joint forest management in Jharkhand, India. World Development 30: 65-72.

Lemenih, M., and M. Bekele. 2008. Participatory forest management, best practices, lessons and challenges encountered: The Ethiopian and Tanzanian experiences. An Evaluation Report, Farm Africa, Addis Ababa. 
Lewbel, A. 2012. Using heteroscedasticity to identify and estimate mismeasured and endogenous regressor models. Journal of Business and Economic Statistics 30: 67-80.

Meaton, J., Abebe, B., Wood, A. 2015. Forest Spice Development: the Use of Value Chain Analysis to Identify Opportunities for the Sustainable Development of Ethiopian Cardamom (Korerima), Sustainable Development, 23: 1-15

Newey, W., L. Powell, and J. Walker. 1990. Semi-parametric estimation of selection models: Some empirical results. American Economic Review 80: 324-328.

Oaxaca, R. 1973. Male-female differentials in urban labor markets. International Economic Review 143: 693-709.

Ostrom, E. 2005. Understanding institutional diversity. Princeton, NJ: Princeton University Press.

Ostrom, E. 2009. A general framework for analyzing sustainability of social-ecological systems, Science, 325, 419-422

Poteete. A., and Ostrom.E. 2004. Heterogeneity, Group Size and Collective Action: The Role of Institutions in Forest Management, Development and Change 35: 435-461

Robinson, E.J.Z., and R.B. Lokina. 2012. Efficiency, enforcement and revenue tradeoffs in participatory forest management: An example from Tanzania. Environment and Development Economics 17: 1-20.

Roy, A.D. 1951. Some thoughts on the distribution of income. Oxford Economic Papers 3: 13546.

Rubin, D. 1973. Matching to remove bias in observational studies. Biometrics 29: 159-183.

Shumeta, Z., K. Urgessa, and Z. Kebebew. 2012. Analysis of market chains of forest coffee in southwest Ethiopia. Academic Journal of Plant Sciences 5: 28-39. 
Shenkute, A., Getachew,Y., Assefa, A., Nuru Adgaba, N., Ganga, G., and Abebe, W . 2012. Honey production systems (Apis mellifera L.) in Kaffa, Sheka and Bench-Maji zones of Ethiopia, Journal of Agricultural Extension and Rural Development , 4:528-541

Sianesi, B. (2004). An evaluation of the active labor market programs in Sweden. Review of Economics and Statistics, 86, 115-133.

Skoufias, E., and R.S. Katayama. 2010. Sources of welfare disparities between and within regions of Brazil: Evidence from the 2002-2003 household budget survey (POF). Journal of Economic Geography 1-22.

SOS Sahel. 2007. Annual Report, SOS Sahel Ethiopia, Addis Ababa.

Stellmacher. T., Grote. U., 2011. Forest Coffee Certification in Ethiopia: Economic Boon or Ecological Bane?, Center for Development Research University of Bonn, Working Paper Series No. 76

Stellmacher, T.,and Mollinga, P. 2009. The institutional sphere of coffee forest management in Ethiopia: local level findings from Koma forest, Kaffa zone, International Journal of Social Forestry, 2:43-66

Stellmacher, T. 2007. The historical development of local forest governance in Ethiopia. From the imperial times to the military regime of the Derg. Afrika Spektrum, 42:519-530

Stock, J.H., and M. Yogo. 2005. Testing for weak instruments in Linear IV Regression. In Identification and Inference for Econometric Models: Essays in Honor of Thomas Rothenberg, D.W.K. Andrews and J.H. Stock. Cambridge: Cambridge University Press, pp. 80-108. 
Takahashi, R., and Y. Todo. 2012. Impact of community-based forest management on forest protection: Evidence from an aid-funded project in Ethiopia. Environmental Management 50: $396-404$.

Tesfaye, Y., A. Roos, B. Campbell, and F. Bohlin. 2010. Forest incomes and poverty alleviation under participatory forest management in the Bale Highlands, southern Ethiopia. International Forestry Review 12: 66-77.

Varughese. G., and Ostrom.E. 2001. The contested role of heterogeneity in collective action: Some evidence from community forestry in Nepal, World Development 5:747-765

Vega, D., Keenan R. 2014 Transaction cost theory of the firm and community forestry enterprises, Journal of Forest Policy and Economics, 42:1-7

Wunder, S. 2001. Poverty alleviation and tropical forests-What scope for synergies? World Development 11: 1817-1833. 